University of Rhode Island

DigitalCommons@URI

Open Access Master's Theses

2021

\title{
THE EFFECTS OF MESSAGE FRAMING ON RESPONSE TO PLASTIC REDUCTION POLICIES
}

Courtney Milley

University of Rhode Island, courtneymilley3@gmail.com

Follow this and additional works at: https://digitalcommons.uri.edu/theses

\section{Recommended Citation}

Milley, Courtney, "THE EFFECTS OF MESSAGE FRAMING ON RESPONSE TO PLASTIC REDUCTION POLICIES" (2021). Open Access Master's Theses. Paper 1940.

https://digitalcommons.uri.edu/theses/1940

This Thesis is brought to you for free and open access by DigitalCommons@URI. It has been accepted for inclusion in Open Access Master's Theses by an authorized administrator of DigitalCommons@URI. For more information, please contact digitalcommons-group@uri.edu. 
THE EFFECTS OF MESSAGE FRAMING ON RESPONSE

TO PLASTIC REDUCTION POLICIES

BY

COURTNEY MILLEY

A THESIS SUBMITTED IN PARTIAL FULFILLMENT OF THE

REQUIREMENTS FOR THE DEGREE OF

MASTERS OF ARTS

IN

MARINE AFFAIRS

UNIVERSITY OF RHODE ISLAND

2021 


\section{MASTER OF ARTS IN MARINE AFFAIRS THESIS}

$\mathrm{OF}$

COURTNEY MILLEY

APPROVED:

Thesis Committee: David Bidwell Elizabeth Mendenhall

Colleen Mouw

Major Professor Emily Diamond

Brenton DeBoef DEAN OF THE GRADUATE SCHOOL

UNIVERSITY OF RHODE ISLAND

2021 


\begin{abstract}
Academic literature to date has effectively proven the scale of plastic pollution's harm to the environment. Some scholars have even argued that it should be discussed broadly in society as a crisis (Mæland \& Staupe-Delgado 2019). To reduce plastic pollution, potential policies need widespread support. Existing literature shows framing manipulations can influence opinion and care for plastic pollution but have not been tied to policy support. This study looked to assess the difference in policy support between groups framed with plastic pollution contributing to climate change causing emissions, plastic pollution endangering charismatic animals, or a control framing with simple information regarding how plastic enters the environment. The hypothesis being tested was that a climate change frame would be more impactful than a charismatic animal frame and therefore be associated with higher policy support. This was tested through a survey experiment of 600 respondents on an online survey platform. Analysis was conducted through SPSS using two regression models for accuracy. The hypothesis was not supported; overall, the control framing and charismatic animal frames were associated with higher support of the most outcome variables. This shows that plastic reduction policies with strong framing may trigger strong identities, and therefore simple explanatory information may be more sufficient. Furthermore, this paper discusses the impact of framing on political and sex subgroups, elucidating a clearer understanding of how these identities differ in support of plastic reduction policies and behavior changes.
\end{abstract}




\section{ACKNOWLEDGMENTS}

I would like to formally thank my major professor, Dr. Emily Diamond for her guidance, patience and understanding in the completion of this thesis. Her work in communication framing inspired me to pursue a new avenue of science in which I did not have previous experience. Her patience and guidance helped me to ensure timely completion of this project, and has greatly expanded my understanding of human behavior, and statistical analysis. I would also like to thank my committee members Dr. Mendenhall, Dr. Mouw and Dr. Bidwell for their support throughout this project. I would like to thank the entire University of Rhode Island Marine Affairs department, especially my 2021 cohort, who have kept me upbeat and excited throughout this process and have never ceased to amaze me with their own talents. To Kyle, Eliya, Lauren and Clay, without your support I never would have gotten through the challenging year that was attempting to complete a master's degree during a global pandemic. 


\section{TABLE OF CONTENTS}

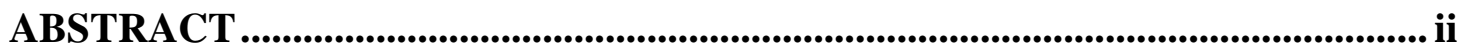

ACKNOWLEDGMENTS ....................................................................................................... iii

TABLE OF CONTENTS................................................................................. iv

LIST OF TABLES .................................................................................................................... v

LIST OF FIGURES ................................................................................................................. vi

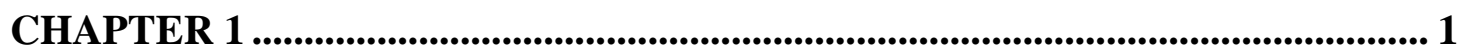

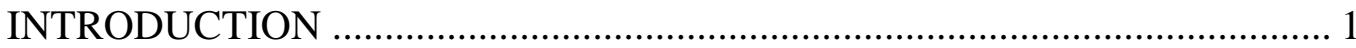

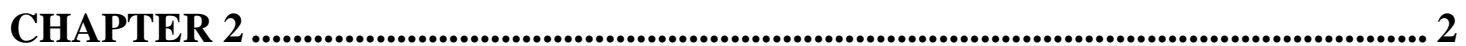

REVIEW OF LITERATURE ………………………….............................. 2

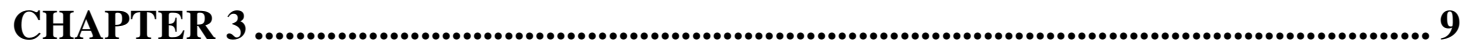

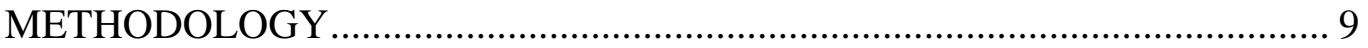

CHAPTER 4 ............................................................................................................................. 16

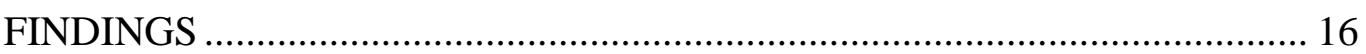

CHAPTER 5 .......................................................................................................................... 33

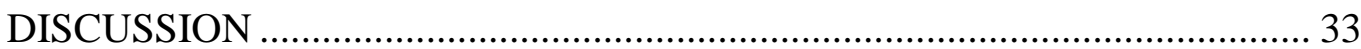

APPENDICES ...................................................................................................................... 39

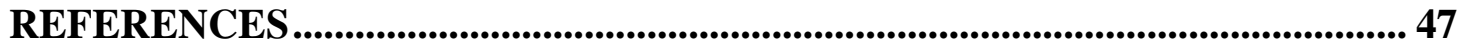




\section{LIST OF TABLES}

TABLE

PAGE

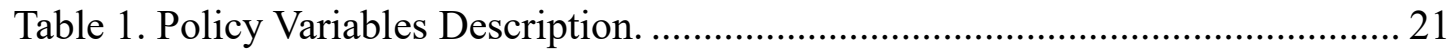

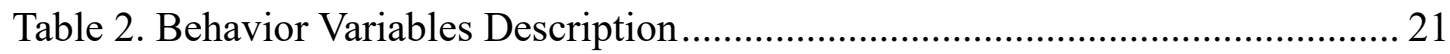

Table 3. Full Sample OLS Regression Results of Policy Variables .............................. 23

Table 4. Full Sample OLS Regression Results of Behavior Variables......................... 24

Table 5. Framing Group Distributions-Political Party Subgroups ............................... 25

Table 6. Republican Party Subgroup OLS Regression Results.................................... 26

Table 7. Independent/No Party Subgroup OLS Regression Results ............................ 29

Table 8. Democratic Party Subgroup OLS Regression Results .................................... 30

Table 9. Framing Group Distributions-Sex Subgroups …………………………..... 31

Table 10. Male-Identifying Subgroup OLS Regression Results.................................. 32

Table 11. Female-Identifying Subgroup OLS Regression Results ............................... 32 


\section{LIST OF FIGURES}

$\begin{array}{lll}\text { FIGURE PAGE } & \text { PAT }\end{array}$

Figure 1. Distribution of Sample Demographics ............................................... 20 


\section{CHAPTER 1}

\section{INTRODUCTION}

Plastic pollution, specifically marine plastic pollution (or debris) is a global problem. Research continues to emerge about the true impact plastic pollution has on the health of the ecosystem as well as the health of humans. Message framing describes a particular approach used to communicate information in a different context to garner support. Public perception and support are extremely important drivers of policy change. Therefore, continued research into the overarching impacts of plastic pollution will be unhelpful if the communication of the problem does not resonate with the public. However, there is little existing research examining message framing of plastic pollution in conjunction with policies to reduce the problem. This study aims to answer the question: are we effectively communicating the plastic pollution problem to the public? Do Americans have higher support for plastic reduction policies when it is communicated as contributing to global emissions, or when framed as impacting charismatic animals? 


\section{CHAPTER 2}

\section{REVIEW OF LITERATURE}

\section{Plastic Pollution}

Academic literature to date has effectively proven the scale of plastic pollution's harm to the environment. Some scholars have even argued that it should be discussed broadly in society as a crisis (Mæland \& Staupe-Delgado 2019). Plastic pollution has been shown to impact marine mammals through entanglement and ingestion leading to disease, starvation, and death (Baulch \& Perry 2014; Eriksen et al. 2014; Gregory 2009; Mæland \& Staupe-Delgado 2019). Plastic pollution has been found to cost popular vacation sites hundreds of millions of dollars in tourism revenue (Jang et al. 2014), billions of dollars in disturbed ecosystem services (Beaumont et al. 2019), and billions of dollars in clean-up costs (Willis et al. 2018). Evidence is emerging of human health consequences of plastics in the food chain (Andrady 2011; Beaumont et al. 2019). Plastic has been shown to be a vector for disease and antibiotic resistant bacteria (Guo 2020) as well as a vector for transporting invasive species (Derraik 2002). Large accumulations of plastic debris are known to lead to anoxia in the environment by inhibiting the proper exchange of gases throughout the water column (Goldberg 1994). Plastic debris affects every aspect of the marine environment: from the deep-sea (Chiba et al. 2018) to coral reefs (Lamb et al. 2018) to surface waters of all major oceans (Eriksen et al. 2014).

Research is recently beginning to emerge about the contribution of plastic

production, recycling, and degradation to greenhouse gas emissions, and therefore 
climate change. Royer and colleagues (2017) found that when plastic's life culminates in the environment, solar radiation and other environmental processes lead to release of methane and ethylene, two greenhouse gases. Their research found that once plastics begin to degrade and release these gases, they continue for the entirety of their life and as they break up into smaller pieces the release of gas accelerates (Royer et al. 2017). Another study estimated the total greenhouse gas emissions from the plastic industry, from extraction to end of life, to be approximately, "10-13\% of the total remaining carbon budget" (Shen et al. 2020) globally. Another estimate says that the $10 \%$ contribution estimate is likely too low as it does not include the recycling industry in that estimate (Vince \& Stoett 2018). Royer and colleagues (2017) conclude that the contribution of the plastic industry to climate change, and greenhouse gas emissions is something that absolutely cannot be ignored (Shen et al. 2020). Furthermore, Zheng and Suh (2019) hypothesize that comprehensive multi-faceted solutions need to be implemented aggressively in order to reduce the overall greenhouse gas contributions of the plastic industry; recycling alone, or replacing petroleum- with bio-based plastics alone will not be enough. This research has only been conducted in the past few years and is therefore an avenue for new study and an approach that I believe is not widespread enough in general public rhetoric.

It is known that humans are the cause of marine plastic debris (Henderson \& Green 2020). Therefore, I believe we first need to focus our efforts on improving how we communicate plastic to the public and understanding how these communication efforts influence policy. Effective communication is the most important avenue for gaining public acceptance of policy, but this is largely overlooked. There are studies 
which look at the framing of plastic pollution through evoking emotions, (Baek \& Yoon 2017; Septianto \& Lee 2019) and understanding the public's perception of the scale of the problem (Dilkes-Hoffman et. al. 2019), but they are not connected to policy support. It had been shown that science can be taught repeatedly, but if the frame is not effective the information will not be perceived in the way it was intended (Chong \& Druckman 2007).

Few studies have been conducted to understand the way the public perceives plastic pollution. The existing studies have looked specifically at manipulating feelings (Septianto \& Lee 2019), relating plastic pollution to human health (Morrissey 2019) or 'tax' versus 'fee' marketing (Muralidharan \& Sheehan 2016). The findings from these studies were significant in beginning to understand how the public perceives the problem of plastic pollution, but none of the authors tied these perceptions or opinions to policy. This represents an important missing piece in the literature. For policy to be effective it must be understood how these frames lead people to interpret policy options. Henderson and Green (2020) found that their respondents did not understand their personal connection to the plastic pollution problem. One participant in the study even said, "'I thought it was just bad for the environment. I didn't think it harmed $u s "$ " (Henderson \& Green 2020). This shows that the public is not getting the correct message on the enormous impacts of plastic pollution. Pahl and Wyles (2017) even call for behavioral experiments to be conducted to help solve the plastic pollution problem, "our recommendation is that strategies for reducing marine litter and microplastics should be guided by behavioral [sic] science" (Pahl \& Wyles 2017) further emphasizing the importance of this study. 


\section{Framing}

The impact of framing was initially described by Tversky and Kahneman who viewed it as a deviation from rational decision-making (Tversky \& Kahneman 1981). Their study, famously known as the Asian disease experiment, illustrates the importance of framing. This experiment examined a novel disease which infected 800 people and measured difference in policy support between one event in which 600 of 800 people were saved, or 200 died. Both scenarios are the same net loss, but they found that in scenarios of gains people tend to be risk-averse, while in scenarios of loss people are risk taking (Tversky \& Kahneman 1981). They set the foundation for understanding that people perceive and interpret identical information differently depending on the presentation of the information, or the frame of the information. Framing is influenced by organization the human brain conducts unconsciously, where incoming knowledge is defined through existing frames and information (Lakoff 2010). Further research has supported that the way information is presented to an individual can change their opinion based on which internal brain frames are ignited (Druckman 2001, Lakoff 2011, Matthes 2008, Spence \& Pidgeon 2010). While it has been shown there is limited capacity to change existing internal frames, presentation of information is crucial. Presentation allows for different internal frames to be ignited instead of trying to change the beliefs and values of an individual. Emphasis framing, described by Druckman (2001) as, highlighting a certain relevant piece of a story to lead people to make certain considerations, will be used in this experiment. A classic example of this method of framing is a politician discussing an issue from an economic perspective to guide the public to view the problem economically, instead of 
socially. The frames in this study are presenting the same problem, but through a different perspective.

Many framing experiments have been conducted to understand public perception of other environmental problems (Anspach \& Draguljic 2019; Baek \& Yoon 2017; Davis 1995; Spence \& Pidgeon 2010; Von Mossner 2018; Wolsko et al. 2016). I examined these studies to understand the methods the framing experiments employed to be able to apply similar methods to this research design. While research on frames emphasizes the fact that no single framing of an issue will appeal to everyone, due to differing value and belief systems, it is important to understand which are the most effective to the largest sector of people (Lakoff 2010), and understand if there are glaring differences among subgroups. Then, policy and communication can be built from understanding the effective frames.

\section{Charismatic Animals}

Charismatic animals are animals that create large interest from the public, and typically evoke empathy (Courchamp et al. 2018). Charismatic animals have been used as conservation tools, and some conservationists claim they are effective in gaining public attention and thereby conserving the species (Schlagloth et al. 2018). This is also referred to as a flagship species, "popular, charismatic species that serve as symbols and rallying points to stimulate conservation awareness and action” (Heywood \& Watson 1995). However, there is debate over the effectiveness of using a flagship species to create ecosystem effects beyond the individual species (Andelman \& Fagan 2000; Barua et al. 2011; Simberloff 1998). There is also controversy over 
what qualifies as a good flagship species; due to social differences, a flagship species that works in one location, "may or may not be relevant in another" (Frazier 2005). Further, Colléony and co-author's (2017) found that the charisma of a species actually had a negative correlation with the amount of money an individual donated to a conservation effort.

In studies understanding the use of the polar bear as the poster child for climate change, Born (2019) found it was a good representation of one part of the problem but did not make the true scope of the problem understandable. This study found that the polar bear and the Arctic were a distant issue, and people could not connect their actions to that distant problem (Born 2019). It established therefore, that people had a hard time connecting the polar bear to global climate change and further, to their individual actions (Born 2019). Manzo (2010) found that connecting climate change to the images of starving polar bears made it difficult for people to envision a solution. All of this is to say, I question the efficacy of using a flagship species for a problem as large and comprehensive as marine plastic pollution. Therefore, I wanted to be able to understand the way people perceive the information tied to a charismatic animal, without the immediate emotional response to a sad image. I believe the few successes of flagship species have led conservationists to believe attaching a "cute" animal to any environmental problem will increase human desire to solve the problem.

However, this may not be the right choice, especially when the problem has a much larger scope, and a human component, beyond being able to donate to conservation efforts. 
Furthermore, research has been conducted showing that humans display no differences in empathy between an injured animal and an injured human (Angantyr et al. 2011). This could be particularly important, because attaching the plastic pollution problem to the human problem of climate change could therefore evoke similar levels of empathy as connecting to an injured animal. Research has also shown that humans tend to act in their own self-interest surrounding all topics (Nickerson 2002). When considering environmentally related issues, people are much more likely to act when they are intrinsically motivated versus being extrinsically motivated (Nickerson 2002). Thus, by attaching the problem of plastic pollution to a climate change, I believe people will be more powerfully motivated to act.

Furthermore, there are very few research studies comparing the effect of a human impact frame to an animal impact frame for any environmental issue. In a study looking to understand how the public perceived the Deepwater Horizon oil spill and other environmental problems, the authors found that connection to an individual animal is not helpful (Clayton et al. 2013). When conducting their framing experiment about climate change, they found that focusing on a, "specific animal is not effective" (Clayton et al. 2013). We know there are difficulties in encouraging action towards climate change and other environmental problems, however we now know attaching the polar bear image to climate change was not the most effective solution (Born 2019, Manzo 2010). Therefore, there needs to be more research on the most effective way to frame the plastic pollution problem to the public. Therefore, the hypothesis is that framing marine plastic debris as a climate change causing emissions problem will 
cause Americans to be more receptive to plastic reduction policies compared to framing marine plastic debris as a problem for charismatic animals. 


\section{CHAPTER 3}

\section{METHODOLOGY}

The hypothesis, that a climate change frame will be associated with higher levels of support for action on plastic pollution compared to a charismatic animal or simple explanatory information, was tested through an experimental survey on a paid online survey platform Prolific among United States citizens. Prolific is a crowdsourced survey platform used for academic and scientific research, which has higher diversity of participants than similar platforms (Palan \& Schitter 2017). The survey was designed and run through Qualtrics, and all participants were gathered and paid through Prolific. Six hundred participants completed the experiment, these 600 participants were randomly divided into three equal groups: a control group, charismatic animal group and climate change group. After reading the consent form and a paragraph describing the study, all the respondents received an informational paragraph about plastic pollution which served as their treatment. Informational paragraphs were used for all treatments to ensure there was no difference in media types. An image could have been used for the charismatic animal framing however it would have been difficult to ensure equality with an image representing climate change, or the control framing. Informational paragraphs were therefore believed to be the most equal way to present all framing manipulations. 


\section{Treatments}

The below paragraph is what all respondents read prior to the survey beginning. This informational paragraph which all respondents received-regardless of framing group — was gathered from the US National Oceanographic and Atmospheric Administration (NOAA) and discussed the pathways for plastic entering our environment. The respondents who received only this information, and no further information, are considered the control group.

"According to the National Oceanographic and Atmospheric Administration (NOAA), one-third to two-thirds of marine plastic debris is from everyday human use.

'When consumer goods, often single-use disposables are littered or improperly managed, this trash can find its way into rivers, streams and other waterways. These ultimately empty into our oceans, where the trash becomes marine debris. One third to two-thirds of the debris we [collect] on beaches comes from single-use, disposable plastic packaging from food and beverage-related goods and services (things like plastic cups, bottles, straws, utensils and stirrers).",

"The solution to this problem is a reduction in production and use of plastic products."

Two of the three groups then received different framing manipulations as it relates to plastic pollution: one discussed plastic pollution from a climate change frame (climate change treatment group), and one discussed plastic pollution from a charismatic animal frame (charismatic animal treatment group. Text for all three groups included the same final sentence to control for respondents imagining their own scenario for solving the problem. This was included to ensure they understood the solution to both problems was the same.

\section{Climate change message:}

"In addition, the Center for International Environmental Law (CIEL) reports: 'Plastic is made from chemicals sourced from fossil fuels, and the fossil fuel and plastic industries are deeply connected. Emissions from plastic production 
and incineration could account for 56 gigatons of carbon between [2017] and 2050. That's almost 50 times the annual emissions of all the coal power plants in the U.S.'

'The key message that people should take away is that the plastic crisis is a climate crisis hiding in plain sight.'

The solution to this problem is a reduction in production and use of plastic products."

Charismatic animal message:

"In addition, the World Wildlife Fund (WWF) reports:

'Globally it is estimated that approximately $52 \%$ of all sea turtles have eaten plastic [...] a turtle has a $22 \%$ chance of dying if it eats just one piece of plastic.'

'Sea turtles think they're consuming some of their staple foods when really they're welcoming harmful substances into their digestive tract. Nearly all species of sea turtle are classified as Endangered and plastic is doing more than its share of damage.'

The solution to this problem is a reduction in production and use of plastic products."

\section{Variables}

The respondents were asked if they believed climate change was caused by human actions (climate problem) prior to the framing manipulation. This variable served as a control to better understand the respondents' prior environmental attitudes and beliefs and was measured on a 5-point scale from strongly disagree to strongly agree. The dependent variable questions followed. They were asked their likelihood to support policy options, ranging in breadth of targeted items. These policy options were: single-use plastic straw bans (straw), single-use plastic bag bans (bag), other single-use plastic bans such as single-use utensils (other), and extended producer responsibility $(E P R)$. Extended producer responsibility is a policy which puts the burden of management, or recycling onto the producer of the plastic, either through taxation, return schemes, or requirements for materials to be more widely 
recycled or reused. All policy variables were explained to participants to ensure they had the same understanding of the policy. Support for policies does not indicate success or efficiency of policies, but instead general public support which may indicate likelihood for these policies to become legislation. Questions about the respondent's behaviors in the next 30 days further served as outcome variables. They were asked their likelihood to engage in moderate reduction of personal singleuse plastic consumption, such as using reusable bags or reusable straws (mod). They were asked their likelihood to engage in drastic reduction of personal single-use plastic consumption, such as buying groceries from a bulk store (drastic). They were also asked their likelihood to attend or organize a beach clean-up (clean-up), or to become more politically involved in the plastic pollution issue, such as voting for a representative who advocates for plastic reduction policies (politic). All above dependent variables were measured on a 7-point scale from strongly oppose to strongly support (for policy variables) and from extremely unlikely to extremely likely (for behavior variables).

The final dependent variable asked the respondents if they would like to donate any portion of their compensation from taking the survey to an organization pushing for plastic pollution policies-5Gyres (donate). This was included as another test of behavior of participants, to supplement a reported willingness to support through their survey responses and was measured through a slider scale, allowing them to choose any amount, from $\$ 0.00$ to $\$ 0.66$. The amount was not actually donated (a common practice). The respondents were debriefed that this was a behavioral measure, and all respondents received compensation within seven days. 
Simple demographic data was collected through the survey, including race, age (grouped as a range), political party affiliation, political leaning, education level, and distance the respondents live from the ocean (distance). This data was supplemented by Prolific's demographic data when the respondents did not answer a specific demographic question within the survey. Prolific collects and reports demographic data of race, sex, age, country of birth, and current country. This demographic data was also used to remove the responses from individuals who were neither from, nor currently living in the United States. All questions were recoded into numeric data for ease of analysis. The table of recoded values can be found in the appendix.

\section{Survey Method}

The survey was posted on Prolific, with a brief message explaining this study looked to understand perception of plastic reduction policies. Participants can choose to take part in the survey. Each survey took approximately five minutes to complete. To reduce the possibility of people skipping through the survey and not reading everything in its entirety, the page with the framing message had a 15 second timer, so the respondents could not skip through it immediately.

The survey responses were downloaded from Qualtrics, then cleaned with the following steps in an excel file. There were 609 total responses, 13 of which were deleted because despite being screened through Prolific that they had to be in the United States, these individuals were neither from nor currently residing in the US. Survey responses from three participants were deleted for having multiple questions left blank. After these deletions, there remained a total of 199 in the control group, 194 
in the climate frame group and 200 in the charismatic animal frame. A treatment check was also included in the survey, following the framing page. This question asked the respondents what the information on the previous page was about, this had a two-fold purpose of reiterating the treatment, and ensuring the participants were spending adequate time and energy responding to the survey. Respondents who completed all the questions but failed the treatment check by incorrectly answering the question on the topic of the information they received, are included in the above numbers, but these 81 responses were later removed. Only respondents in the two treatment groups were given this treatment check question. There was a higher proportion of respondents who got this treatment check wrong than expected, about $13 \%$ answered the treatment check incorrectly. It is possible they viewed the question as being unclear, could not remember the information they had just finished reading since it was on a separate page, or did not actually read the information. However, I believe the question was fair and worded correctly as it passed through multiple reviewer's hands before it was published online.

After initial data clean-up, and respondents who incorrectly answered the treatment check were removed, there were four total missing values from other questions, each from different participants, on different questions (1 in bag, 1 in drastic, and 2 in clean-up) these were all dealt with by imputation by mode (a statistical practice of replacing a missing value with an average). The mode was used because mean is not appropriate with Likert scale data. This was done to keep response numbers high, instead of removing all responses from these 5 individuals. Due to the low number of missing values, the imputation should not alter any 
results. After an analysis showing that answering the treatment check correctly was statistically significant in the responses to the rest of the survey, those who answered incorrectly were removed. This left the sample with 512 responses, $161(31.4 \%)$ in the climate change frame group, $152(29.7 \%)$ in the charismatic animal group, and 199 (38.9\%) in the control group. All results to follow will be based on these numbers.

\section{Analysis Method}

The data was then analyzed using IBM's SPSS analysis software. ANOVA tests were run on the population and each treatment group to ensure there were no significant differences in demographics between the participants that were randomly selected to each group. These results revealed there were no demographic differences between groups. Ordered logit (OLogit) tests were run first, then ordinary least squares (OLS) tests were run, with each policy and personal behavior question as dependent variables and all demographics and treatment assignment as independent variables. Given similar levels of significance, and the ease of interpreting OLS, these results were used for interpretation and are presented here. The OLogit test results can be found in the appendix.

After the full sample analyses, the sample was broken into political party affiliations and sex subgroups, and OLS tests were run on these subgroupings. Both subgroupings are supported in the literature, and by statistical significance in the full sample regressions. Political party is a strong identity which can inform people's policy preferences (Mayer 2017). People show preferences for policies that they believe are along party lines, even if their true beliefs do not actually align with these 
policies (Mayer 2017). Therefore, the sample was separated into political party affiliation to assess the difference in framing effects among these different parties. Overall, there was a stronger effect from the control framing on the Independent/No party subgroup illustrating that they were likely influenced by the framing, instead of political party ideologies. The Republican and Democratic samples still had political ideologies that they stuck to and saw smaller framing effects.

General consensus within the existing literature is that females are more impacted by environmental messages, have higher environmental concern compared to males (Mueller \& Mullenbach 2018; Xiao \& McCright 2012), and report higher levels of empathy for animals compared to adult humans (Angantyr, Eklund \& Hansen 2015). Therefore, the sample was also broken into to see if there was a difference in the effect of the framing manipulations between males or females in this sample. There were general differences observed between these two subgroups; overall females were more influenced by the charismatic animal frame whereas the males were more influenced by the control framing, which will subsequently be discussed further. 


\section{CHAPTER 4}

\section{FINDINGS}

The framing experiment conducted in this study had a slight skew in demographics. The sample was skewed towards a younger demographic, there were slightly more females than males, and was skewed Democratic. Due to the nature of this experiment, these differences do not negate the ability to draw conclusions about the population, but they are important to note. Overall, the sample had high levels of support for all policies and personal behavior changes. Among the full sample, the control treatment and the charismatic animal treatments were associated with the highest level of support. The sample was then broken into political party subgroups and sex subgroups. The control framing was associated with the highest support for policies and behaviors among Independents/No party affiliation, and males. The charismatic animal framing was associated with the highest support for policies and behaviors among Republicans and females. There was no trend in significance of one treatment group among Democrats, as there was an equal number of dependent variables with significance among treatment groupings.

\section{Descriptive Statistics}

In the sample of 512 people, after removing the responses from individuals who failed the treatment check, $67.2 \%$ (344) were white, $13.9 \%$ (71) were Asian/Pacific Islander. Only 8.6\% (44) were Hispanic or Latino, 4.7\% (24) were Black or African American and the remaining 5.7\% (29) identified as Native American or American Indian, other, or preferred not to answer. This is a slightly 
higher proportion of white individuals than in the US population, however given the fact this was an experimental survey, the proportions of demographics did not need to perfectly mimic the proportions of the United States population to draw conclusions. The random assignment of respondents within the treatment groups will theoretically account for any variances and therefore will allow for conclusions to be drawn from the population.

The sample was slightly more female, $54.9 \%$ (281), than male $39.1 \%$ (200). Twenty-one individuals (6.1\%) identified as trans-males, trans-females, nonbinary or other. For the sample's education level, 34.6\% (177) of the sample had “some college" experience, 37.9\% (194) had a bachelor's degree. Twelve percent (63) had a high school diploma or equivalent, $12.3 \%$ (63) had a masters or other professional degree, and 2.9\% (15) had a doctorate degree. Thirty-one percent (159) of the sample was between 18 and 24 years of age, and 39.1\% (200) were between 25 and 34 years of age. Sixteen percent (83) were 35 to 44 , and the other $6.3 \%$ were above 45 , only $1.6 \%$ (8) were over the age of 65 . This means the majority of the sample (about 70\%) was between 18 and 34, so the sample had an age skew. The impact of this is discussed further in the results. The ANOVA resulted in no significance difference in demographics between the three groups.

Approximately half (52.3\%) of the sample lived more than 100 miles from the ocean. This likely impacted the response to attending a beach clean-up (clean-up); as this was the least supported behavior change, because someone who would have to travel more than 100 miles to get to the ocean is unlikely to engage in a beach clean- 
up in the next 30-days. The majority (57.6\%) of the respondents were Democrats (295 individuals), $21.5 \%$ (110) were Independent, $11.7 \%$ (60) were Republican, and 47 (9.2\%) had no party affiliation. Political leaning was also assessed: 18 individuals (3.5\%) identified as very conservative, 58 (11.3\%) were moderately conservative, 99 (19.3\%) were neither conservative nor liberal, $180(35.2 \%)$ were moderately liberal and $155(30.3 \%)$ were very liberal. The impact of these political affiliations is also considered further in the discussion section.
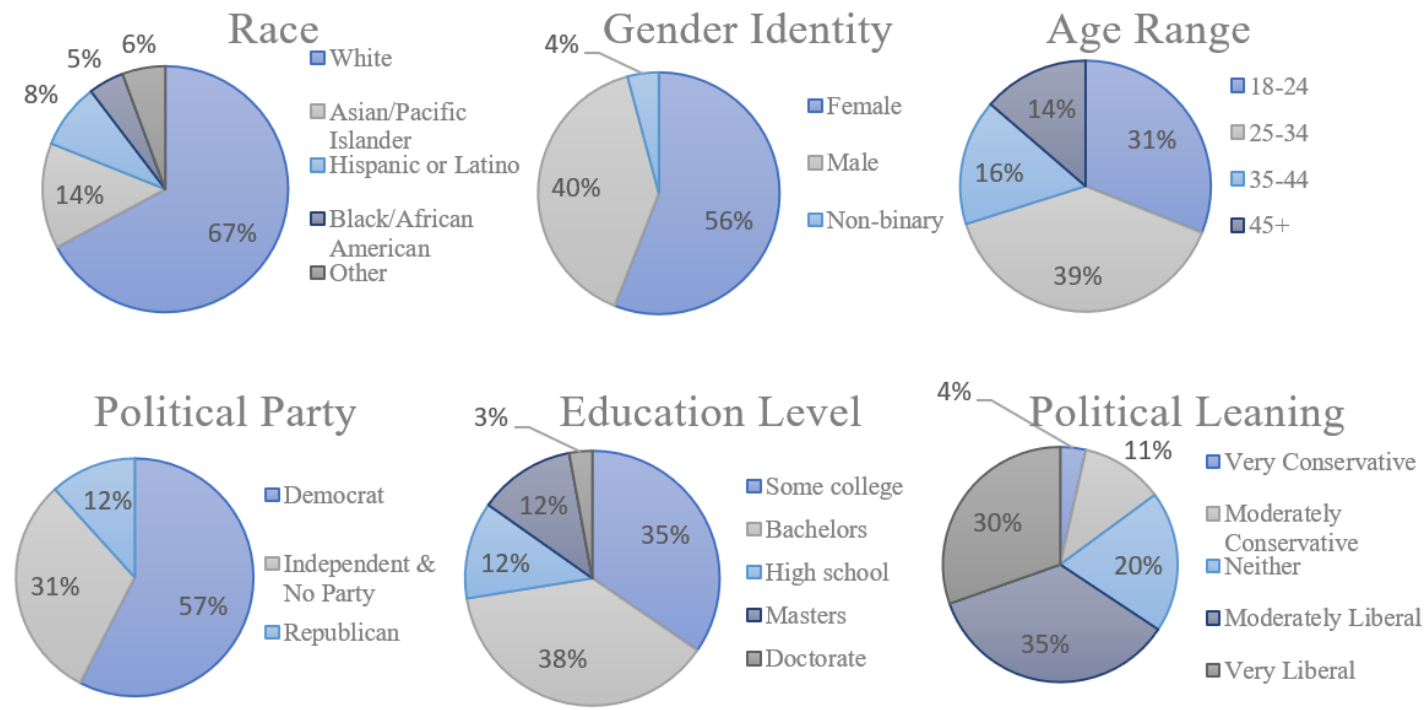

Figure 1: Distributions of Sample Demographics

\section{Variable Descriptive Statistics}

About $53 \%$ of respondents said they strongly agree that climate change is caused by human actions. These results indicate that there is a high level of agreement about human caused environmental problems among this sample; and significantly influenced the support of policy and behavior variables. The dependent variables of

policy support and their distributions are highlighted in table 1. Behavior variables and their distributions are highlighted in table 2. 


\section{Table 1: Policy Variables Description}

(description given to respondents and descriptive statistics)

\begin{tabular}{|c|c|c|c|c|}
\hline $\begin{array}{l}\text { Strongly } \\
\text { Oppose }\end{array}$ & Oppose & $\begin{array}{l}\text { Somewha } \\
\text { Oppose }\end{array}$ & Neither & $\begin{array}{l}\text { Somewhat } \\
\text { Support }\end{array}$ \\
\hline
\end{tabular}

Straw: would make it illegal for restaurants to supply plastic straws with drinks
$26(5.1 \%)$
$32(6.3 \%)$
$51(10 \%)$
$46(9 \%)$
$77(15 \%)$
$128(25 \%)$
$152(29.7 \%)$

Bag: would make it illegal for stores to give out plastic bags with purchases
$14(2.7 \%)$
$17(3.3 \%)$
$39(7.6 \%)$
$38(7.4 \%)$
$82(16 \%)$
$141(27.5 \%)$
$181(35.4 \%)$

Other: making it illegal to sell other single use plastic items such as single use water bottles or single-use utensils?
$22(4.3 \%)$
$32(6.3 \%)$
$43(8.4 \%)$
$60(11.7 \%)$
$117(22.9 \%)$
$119(23.3 \%)$
$119(23.2 \%)$

EPR: puts the cost of plastic on the producer instead of society. For example, making Coca Cola responsible for recycling of all plastic bottles they produce.
$7(1.4 \%)$
$15(2.9 \%)$
$11(2.1 \%)$
$34(6.6 \%)$
$72(14.4 \%)$
$101(19.7 \%)$
$272(53.1 \%)$

Table 2: Behavior Variables Description

(description given to respondents and descriptive statistics)

\begin{tabular}{|c|c|c|c|c|}
\hline $\begin{array}{l}\text { Extremely } \\
\text { unlikely }\end{array}$ & Unlikely & \multicolumn{2}{|c|}{$\begin{array}{l}\text { Somewhat Neutral } \\
\text { Unlikely }\end{array}$} & $\begin{array}{l}\text { Somewhat } \\
\text { Likely }\end{array}$ \\
\hline
\end{tabular}

Mod: Moderate Behavior Change- Moderately reduce your personal plastic use (not use single use straws, bring a reusable coffee mug to the coffee shop, bring reusable bags to the grocery store).
$16(3.1 \%)$
$15(2.9 \%)$
$15(2.9 \%)$
$30(5.9 \%)$
$121(23.6 \%)$
$153(29.9 \%)$
$162(31.6 \%)$

Drastic: Drastic Behavior Change- Drastically reduce your personal plastic use (buy groceries from bulk stores, use toiletries packaged in alternative ways).
$26(5.1 \%)$
$36(7 \%)$
$35(6.8 \%)$
$56(10.9 \%) \quad 136(26.6 \%)$
$133(26 \%)$
$90(17.6 \%)$

Politic: Political Involvement- Become more politically involved on the issue of plastics pollution (voting for representatives that advocate reducing marine plastic pollution, signing petitions).
$71(13.9 \%)$
$57(11.1 \%) \quad 40(7.8 \%)$
$67(13.3 \%)$
$131(25.6 \%)$
$92(18 \%)$
$54(10.5 \%)$

Clean-Up: Attend or organize a local beach clean-up

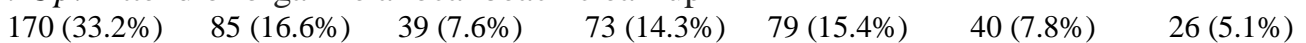

The most supported policy was extended producer responsibility $(E P R)$ with $53.1 \%$ of respondents answering that they strongly support such a policy. This aligns with current research on environmental policy support showing that Americans tend to support policies that regulate industry and therefore do not require individual action (Dietz, Dan, \& Shwom 2007). This suggests that EPR would garner large support and 
therefore could be possible for the United States to implement for tackling plastic pollution. The mean donation to 5Gyres (donation) was $\$ 0.20$ ( $\sigma: 0.21$; min: 0.00, max: 0.66), indicating there was an overall level of donation amongst the sample.

\section{Statistical Analysis}

Following descriptive analysis of variables, the regression models were run. Tables 3 and 4 show the output of the OLS regression models for the full sample. The results are separated between policy outcome variables (table 3) and behavior outcome variables (table 4) for ease of reading. There was some significance in the framing effects when testing with the full sample. In general, the control framing and charismatic animal framings were associated with higher support of policies and personal behavior changes compared to the climate change treatment framing.

\section{Policy Outcome Variables}

Policy outcome variables were significantly associated with treatment group and other independent variables, as shown in table 3. The charismatic animal framing was associated with a $3.8 \%$ higher likelihood to support a bag ban with marginal significance $(\mathrm{p}<0.10)$ and $5.6 \%$ higher support of a straw ban $(\mathrm{p}<0.05)$ compared to the climate change framing group as shown in table 3. A stronger belief in climate change being a problem caused by human actions (climate problem) was also associated with higher support of all policy variables. As belief in climate change being caused by human actions increased, support for all policy variables also increased. 


\begin{tabular}{|c|c|c|c|c|}
\hline \multicolumn{5}{|c|}{ Table 3: Full Sample OLS Regression Results of Policy Variables } \\
\hline \multicolumn{5}{|c|}{ Outcome Variables } \\
\hline & Bag & Straw & Other & $E P R$ \\
\hline $\begin{array}{l}\text { Climate:1/ } \\
\text { Control: } 0^{\circ}\end{array}$ & $\begin{array}{l}-0.138 \\
(0.141)\end{array}$ & $\begin{array}{l}-0.049 \\
(0.174)\end{array}$ & $\begin{array}{l}-0.089 \\
(0.159)\end{array}$ & $\begin{array}{l}-0.151 \\
(0.130)\end{array}$ \\
\hline $\begin{array}{l}\text { Animal:1/ } \\
\text { Control:0 }\end{array}$ & $\begin{array}{l}0.117 \\
(0.147)\end{array}$ & $\begin{array}{l}0.334 \bullet \\
(0.177)\end{array}$ & $\begin{array}{l}0.128 \\
(0.161)\end{array}$ & $\begin{array}{l}-0.095 \\
(0.128)\end{array}$ \\
\hline $\begin{array}{l}\text { Animal:0/ } \\
\text { Climate: }{ }^{\circ}\end{array}$ & $\begin{array}{l}-0.269 \bullet \\
(0.155)\end{array}$ & $\begin{array}{l}-0.392 * \\
(0.184)\end{array}$ & $\begin{array}{l}-0.191 \\
(0.167)\end{array}$ & $\begin{array}{l}-0.040 \\
(0.139)\end{array}$ \\
\hline $\begin{array}{l}\text { Climate } \\
\text { Problem }\end{array}$ & $\begin{array}{l}0.358 * * * \\
(0.104)\end{array}$ & $\begin{array}{l}0.250^{*} \\
(0.128)\end{array}$ & $\begin{array}{l}0.424 * * * \\
(0.118)\end{array}$ & $\begin{array}{l}0.192 * \\
(0.096)\end{array}$ \\
\hline Distance & $\begin{array}{l}-0.051 \\
(0.043)\end{array}$ & $\begin{array}{l}-0.004 \\
(0.053)\end{array}$ & $\begin{array}{l}-0.004 \\
(0.048)\end{array}$ & $\begin{array}{l}-0.035 \\
(0.039)\end{array}$ \\
\hline Leaning & $\begin{array}{l}0.085 \\
(0.097)\end{array}$ & $\begin{array}{l}-0.116 \\
(0.119)\end{array}$ & $\begin{array}{l}0.025 \\
(0.109)\end{array}$ & $\begin{array}{l}0.237 \text { ** } \\
(0.089)\end{array}$ \\
\hline Party & $\begin{array}{l}0.328^{*} \\
(0.146)\end{array}$ & $\begin{array}{l}0.420^{*} \\
(0.179)\end{array}$ & $\begin{array}{l}0.264 \\
(0.164)\end{array}$ & $\begin{array}{l}0.147 \\
(0.134)\end{array}$ \\
\hline EdLevel & $\begin{array}{l}0.003 \\
(0.080)\end{array}$ & $\begin{array}{l}0.169 \bullet \\
(0.099)\end{array}$ & $\begin{array}{l}0.013 \\
(0.091)\end{array}$ & $\begin{array}{l}-0.011 \\
(0.074)\end{array}$ \\
\hline Age & $\begin{array}{l}0.013 \\
(0.069)\end{array}$ & $\begin{array}{l}0.026 \\
(0.085)\end{array}$ & $\begin{array}{l}0.032 \\
(0.078)\end{array}$ & $\begin{array}{l}-0.103 \\
(0.064)\end{array}$ \\
\hline Race & $\begin{array}{l}-0.011 \\
(0.043)\end{array}$ & $\begin{array}{l}-0.007 \\
(0.053)\end{array}$ & $\begin{array}{l}0.039 \\
(0.049)\end{array}$ & $\begin{array}{l}0.075 \bullet \\
(0.040)\end{array}$ \\
\hline Sex & $\begin{array}{l}-0.143 \\
(0.093)\end{array}$ & $\begin{array}{l}-0.260 * \\
(0.115)\end{array}$ & $\begin{array}{l}-0.023 \\
(0.105)\end{array}$ & $\begin{array}{l}0.072 \\
(0.086)\end{array}$ \\
\hline Adjusted $\mathrm{R}^{2}$ & 0.284 & 0.206 & 0.299 & 0.317 \\
\hline \multicolumn{5}{|c|}{$\begin{array}{l}\text { Significance levels indicated by: } \bullet \mathrm{p} \leq 0.10 * \mathrm{p} \leq 0.05 * * \mathrm{p} \leq 0.01 * * * \mathrm{p} \leq 0.001 \\
\text { Standard error in parentheses } \\
{ }^{\circ} \text { Each treatment indicator variable run independently with the controls, but listed } \\
\text { together for ease of presentation }\end{array}$} \\
\hline
\end{tabular}




\section{Behavior Outcome Variables}

Behavior outcome variables were also significantly associated with treatments, as shown in table 4. Receiving the control frame was associated with a 5.8\% higher likelihood to engage in plastic pollution-relevant political involvement (politic) compared to receiving the climate change frame $(\mathrm{p}<0.05)$. There was no significance of political involvement between the charismatic animal and control frame or the

\begin{tabular}{|c|c|c|c|c|c|}
\hline \multicolumn{6}{|c|}{ Table 4: Full Sample OLS Regression Results of Behavior Variables } \\
\hline \multicolumn{6}{|c|}{ Outcome Variables } \\
\hline & Politic & Mod. & Drastic & Clean-Up & Donate \\
\hline $\begin{array}{l}\text { Climate:1/ } \\
\text { Control: } 0^{\circ}\end{array}$ & $\begin{array}{l}-0.410^{*} \\
(0.179)\end{array}$ & $\begin{array}{l}-0.224 \bullet \\
(0.131)\end{array}$ & $\begin{array}{l}-0.113 \\
(0.154)\end{array}$ & $\begin{array}{l}-0.086 \\
(0.191)\end{array}$ & $\begin{array}{l}-0.001 \\
(0.025)\end{array}$ \\
\hline $\begin{array}{l}\text { Animal:1/ } \\
\text { Control: } 0^{\circ}\end{array}$ & $\begin{array}{l}-0.275 \\
(0.174)\end{array}$ & $\begin{array}{l}-0.009 \\
(0.136)\end{array}$ & $\begin{array}{l}-0.085 \\
(0.170)\end{array}$ & $\begin{array}{l}0.016 \\
(0.196)\end{array}$ & $\begin{array}{l}0.032 \\
(0.024)\end{array}$ \\
\hline $\begin{array}{l}\text { Animal:0/ } \\
\text { Climate: } 1^{\circ}\end{array}$ & $\begin{array}{l}-0.136 \\
(0.206)\end{array}$ & $\begin{array}{l}-0.183 \\
(0.152)\end{array}$ & $\begin{array}{l}-0.010 \\
(0.176)\end{array}$ & $\begin{array}{l}-0.101 \\
(0.213)\end{array}$ & $\begin{array}{l}-0.028 \\
(0.027)\end{array}$ \\
\hline $\begin{array}{l}\text { Climate } \\
\text { Problem }\end{array}$ & $\begin{array}{l}0.197 \\
(0.132)\end{array}$ & $\begin{array}{l}0.048 \\
(0.096)\end{array}$ & $\begin{array}{l}0.131 \\
(0.113)\end{array}$ & $\begin{array}{l}0.029 \\
(0.141)\end{array}$ & $\begin{array}{l}0.016 \\
(-0.018)\end{array}$ \\
\hline Distance & $\begin{array}{l}-0.028 \\
(0.054)\end{array}$ & $\begin{array}{l}-0.057 \\
(0.039)\end{array}$ & $\begin{array}{l}-0.064 \\
(0.046)\end{array}$ & $\begin{array}{l}-0.121 * \\
(0.058)\end{array}$ & $\begin{array}{l}0.013 \bullet \\
(0.008)\end{array}$ \\
\hline Leaning & $\begin{array}{l}0.368 * * \\
(0.122)\end{array}$ & $\begin{array}{l}0.253 * * \\
(0.089)\end{array}$ & $\begin{array}{l}-0.084 \\
(0.105)\end{array}$ & $\begin{array}{l}-0.076 \\
(0.131)\end{array}$ & $\begin{array}{l}0.014 \\
(0.017)\end{array}$ \\
\hline Party & $\begin{array}{l}-0.181 \\
(0.185)\end{array}$ & $\begin{array}{l}-0.036 \\
(0.135)\end{array}$ & $\begin{array}{l}0.076 \\
(0.158)\end{array}$ & $\begin{array}{l}-0.049 \\
(0.197)\end{array}$ & $\begin{array}{l}0.001 \\
(0.026)\end{array}$ \\
\hline EdLevel & $\begin{array}{l}-0.004 \\
(0.102)\end{array}$ & $\begin{array}{l}-0.104 \\
(0.074)\end{array}$ & $\begin{array}{l}-0.024 \\
(0.087)\end{array}$ & $\begin{array}{l}0.113 \\
(0.108)\end{array}$ & $\begin{array}{l}0.019 \\
(0.014)\end{array}$ \\
\hline Age & $\begin{array}{l}-0.078 \\
(0.088)\end{array}$ & $\begin{array}{l}0.092 \\
(0.064)\end{array}$ & $\begin{array}{l}-0.053 \\
(0.075)\end{array}$ & $\begin{array}{l}-0.140 \\
(0.093)\end{array}$ & $\begin{array}{l}0.018 \\
(0.012)\end{array}$ \\
\hline Race & $\begin{array}{l}-0.088 \\
(0.055)\end{array}$ & $\begin{array}{l}0.043 \\
(0.040)\end{array}$ & $\begin{array}{l}0.066 \\
(0.047)\end{array}$ & $\begin{array}{l}0.036 \\
(0.059)\end{array}$ & $\begin{array}{l}-0.001 \\
(0.008)\end{array}$ \\
\hline Sex & $\begin{array}{l}-0.170 \\
(0.118)\end{array}$ & $\begin{array}{l}-0.127 \\
(0.086)\end{array}$ & $\begin{array}{l}-0.128 \\
(0.101)\end{array}$ & $\begin{array}{l}-0.062 \\
(0.126)\end{array}$ & $\begin{array}{l}0.000 \\
(0.017)\end{array}$ \\
\hline Adjusted $\mathrm{R}^{2}$ & 0.250 & 0.318 & 0.223 & 0.136 & 0.138 \\
\hline
\end{tabular}


charismatic animal and climate change frame as shown in table 4. Receiving the control frame was associated with a $3.2 \%$ higher likelihood to engage in moderate personal plastic reduction $(\bmod )$ compared to the climate change frame $(\mathrm{p}<0.10)$. There was no significant difference between the charismatic animal framing and the control framing or the charismatic animal and climate change frame.

\section{Political Party Sub-Groups}

The sample was divided into political party subgroups due to the existing literature demonstrating a strong association between political affiliation and environmental attitudes, as previously described. Table 5 shows the number of respondents among each framing group when broken into this subgrouping.

\begin{tabular}{|llll|}
\hline \multicolumn{4}{|c|}{ Table 5: Framing Group Distributions- Political Party Subgroups } \\
\hline & Control & $\begin{array}{l}\text { Charismatic } \\
\text { Animal }\end{array}$ & Climate Change \\
& & 20 & 17 \\
Republican & 23 & 36 & 56 \\
Independent/No Party & 65 & 96 & 88 \\
Democrat & 111 & \\
\hline
\end{tabular}

When the sample was separated into political parties; some differential treatment effects were observed among subgroups. The Republican-affiliated subgroup was most influenced by the charismatic animal framing, and the Independent/No Party-affiliated subgroup was most influenced by the control framing. The Democratic affiliated subgroup did not have results that indicated a trend of significance for one framing manipulation. 


\section{Republican Party Affiliation}

The Republican affiliated subgroup showed statistically significant treatment effects for a few dependent variables and was most influenced by the charismatic animal framing. This is different compared to the full sample, which was most influenced by both the control and charismatic animal framings. As shown in table 6 , receiving the charismatic animal frame was associated with $15.6 \%$ higher support of a single-use plastic bag ban compared to the control frame $(\mathrm{p}<0.10)$ among Republicans. There was no statistically significant difference between the climate change frame and the control frame, or the climate change frame and the charismatic animal frame among Republicans for bag support. The charismatic animal frame was associated with a $20.3 \%$ higher support of other single-use plastic bans (other) when compared to the climate change frame $(\mathrm{p}<0.05)$. There was no statistically significant

\begin{tabular}{|c|c|c|c|c|c|c|c|c|c|}
\hline \multicolumn{10}{|c|}{ Table 6: Republican Party OLS Regression Results } \\
\hline & Bag & Straw & Other & $E P R$ & Politic & Mod. & Drastic & $\begin{array}{l}\text { Clean- } \\
U p\end{array}$ & Donate \\
\hline Climate: $1 /$ & 0.170 & -0.141 & -0.483 & -0.799 & 0.364 & 0.466 & -0.368 & 0.330 & $-0.153 *$ \\
\hline Control: $0^{\circ}$ & $(0.616)$ & $(0.520)$ & $(0.685)$ & $(0.767)$ & $(0.629)$ & $(0.637)$ & $(0.639)$ & $(0.648)$ & $(0.071)$ \\
\hline Animal:1/ & $1.091 \bullet$ & 0.540 & 0.825 & $(0.119)$ & 0.171 & $1.186^{*}$ & -0.080 & -0.442 & 0.096 \\
\hline Control: $0^{\circ}$ & $(0.578)$ & $(0.533)$ & $(0.490)$ & $(0.612)$ & $(0.604)$ & $(0.569)$ & $(0.507)$ & $(0.571)$ & $(0.091)$ \\
\hline Climate:1/ & -1.201 & -0.947 & $-1.424 *$ & -0.472 & -0.606 & -0.982 & -0.386 & -0.191 & $-0.302 * * *$ \\
\hline Animal: $0^{\circ}$ & $(0.740)$ & $(0.778)$ & $(0.654)$ & $(0.771)$ & $(0.888)$ & $(0.727)$ & $(0.604)$ & $(0.804)$ & $(0.083)$ \\
\hline Adjusted $\mathrm{R}^{2}$ & 0.472 & 0.608 & 0.310 & 0.097 & 0.418 & 0.420 & 0.450 & 0.417 & 0.195 \\
\hline \multicolumn{10}{|c|}{$\begin{array}{l}\text { Significance levels indicated by: } \bullet \mathrm{p} \leq 0.10 * \mathrm{p} \leq 0.05 * * \mathrm{p} \leq 0.01 * * * \mathrm{p} \leq 0.001 \\
\text { Standard error in parentheses } \\
\text { (climate problem, race, age, sex, education level, political leaning and distance were held as controls in this } \\
\text { model) } \\
{ }^{\circ} \text { Each treatment indicator variable was run independently with the controls, but listed } \\
\text { together for ease of presentation }\end{array}$} \\
\hline
\end{tabular}


difference between the climate change frame and the control frame or the charismatic animal frame and the control frame among Republicans for support of other. The charismatic animal frame was associated with a $17 \%$ higher likelihood to engage in moderate personal plastic reduction over the next 30 days ( $m o d$ ) compared to the control frame $(\mathrm{p}<0.05)$ among Republicans. There was no statistically significant difference between the climate change and control frames or the climate change and the charismatic animal frame among Republicans for support of mod. Being in the control group was associated with $2 \%$ higher donation versus the climate change group $(\mathrm{p}<0.05)$ among Republicans. The charismatic animal group was associated with $4 \%$ higher donation over the climate change group $(\mathrm{p}<0.001)$. There was no statistically significant difference in donation between the charismatic animal group and the control group among Republicans.

\section{Independent/No Political Party Affiliation}

Respondents who identified as Independent or no political party affiliation were grouped together for analysis. This created a subgroup of 157 individuals, or $30.7 \%$ of the sample. Overall, these respondents were more influenced by the control framing compared to the treatment frames, there were some significant associations with the charismatic animal frame, but the control was significant for the most outcome variables. This result is more similar to the full sample, as the full sample was also influenced by the control framing and charismatic animal framing. In this subgroup, receiving the control message was associated with $7.4 \%$ higher support for a single-use bag ban ( $b a g$ ) compared to those receiving the climate change frame 
$(\mathrm{p}<0.05)$ as shown in table 7 . There was no significant difference between the control and charismatic animal, or charismatic animal and climate change frames among Independent/No Party for support of bag. The charismatic animal frame was associated with $13.2 \%$ higher support for a single-use straw ban (straw) compared to the climate frame $(\mathrm{p}<0.10)$ among this subgroup. There was no significance between the charismatic animal frame and the control frame, or climate change and the control frames among Independent/No Party for straw. Support for other was associated with 9.8\% higher support $(\mathrm{p}<0.05)$ among the control framing compared to the climate change frame, and $10.5 \%$ higher support $(\mathrm{p}<0.05)$ among the charismatic animal framing compared to the climate change frame. There was no significance between the charismatic animal frame and the control frame among Independents for other.

The control framing was associated with $8.5 \%$ higher support for extended producer responsibility $(E P R)$ compared to the charismatic animal framing $(\mathrm{p}<0.05)$ among the Independent/No Party subgroup. There was no significant difference between the climate change frame and the control frame or the climate change frame and the charismatic animal frame among Independents for support of EPR. The control group was associated with a $15.4 \%$ higher likelihood to engage in politically active behavior such as voting for representatives that advocate for plastic reduction policies (politic) compared to the climate change frame $(\mathrm{p}<0.001)$. The control group was also associated with a $9.9 \%$ higher likelihood for politic compared to the charismatic animal framing $(\mathrm{p}<0.05)$ as shown in table 7 . There was no significant difference in politic likelihood between the climate change frame and the charismatic animal framing among the Independent/No Party subgroup. They were associated with 
the most statistically significant variable associations and had the strongest trend towards one framing.

\begin{tabular}{|c|c|c|c|c|c|c|c|c|c|}
\hline \multicolumn{10}{|c|}{ Table 7: Independent/No Party OLS Regression Results } \\
\hline & Bag & Straw & Other & $E P R$ & Politic & Mod. & Drastic & $\begin{array}{l}\text { Clean } \\
-U p\end{array}$ & Donate \\
\hline Climate: $1 /$ & $-0.516^{*}$ & -0.241 & $-0.684 *$ & -0.338 & $-1.081 * * *$ & -0.244 & -0.194 & -0.149 & 0.026 \\
\hline Control: $0^{\circ}$ & $(0.257)$ & $(0.342)$ & $(0.315)$ & $(0.237)$ & $(0.319)$ & $(0.205)$ & $(0.273)$ & $(0.321)$ & $(0.045)$ \\
\hline Animal:1/ & -0.228 & 0.606 & -0.006 & $-0.596^{*}$ & $-0.692 *$ & -0.269 & -0.207 & 0.287 & 0.047 \\
\hline Control: $0^{\circ}$ & $(0.286)$ & $(0.372)$ & $(0.335)$ & $(0.290)$ & $(0.347)$ & $(0.270)$ & $(0.357)$ & $(0.397)$ & $(0.048)$ \\
\hline Climate:1/ & -0.408 & $-1.023 * *$ & $-0.737 \bullet$ & 0.171 & -0.635 & 0.053 & -0.018 & -0.528 & -.003 \\
\hline Animal: $0^{\circ}$ & $(0.364)$ & $(0.385)$ & $(0.386)$ & $(0.319)$ & $(0.428)$ & $(0.298)$ & $(0.377)$ & $(0.398)$ & $(0.050)$ \\
\hline $\begin{array}{l}\text { Adjusted } \\
\mathrm{R}^{2}\end{array}$ & 0.140 & 0.043 & 0.045 & 0.112 & 0.075 & 0.200 & 0.131 & 0.210 & 0.012 \\
\hline \multicolumn{10}{|c|}{$\begin{array}{l}\text { Significance levels indicated by: } \bullet \mathrm{p} \leq 0.10 * \mathrm{p} \leq 0.05 * * \mathrm{p} \leq 0.01 * * * \mathrm{p} \leq 0.001 \\
\text { Standard error in parentheses } \\
\text { (climate problem, race, age, sex, education level, political leaning and distance were held as controls in this } \\
\text { model) } \\
{ }^{\circ} \text { Each treatment indicator variable was run independently with the controls, but listed together } \\
\text { for ease of presentation }\end{array}$} \\
\hline
\end{tabular}

\section{Democratic Party Affiliation}

Among the respondents that identified as Democrats, there were significant treatment effects seen for two outcome variables; one was more affected by the climate change frame and one was more affected by the control frame as shown in table 8. Overall, these results from the Democratic party showed no significant trend of one treatment group because there was an equal number of variables significantly associated by the climate change frame and the control frame. Receiving the climate frame, compared to the control frame, was associated with a 5.7\% higher support for other single use bans but was associated with a $4.8 \%$ decrease in likelihood to engage in moderate personal plastic reduction $(\bmod )(\mathrm{p}<0.05)$. There were no other statistically significant variables for the Democratic subgroup. 


\begin{tabular}{|c|c|c|c|c|c|c|c|c|c|}
\hline \multicolumn{10}{|c|}{ Table 8: Democratic Party OLS Regression Results } \\
\hline & Bag & Straw & Other & $E P R$ & Politic & Mod & Drastic & $\begin{array}{l}\text { Clean- } \\
\text { Up }\end{array}$ & Donate \\
\hline Climate: $1 /$ & 0.132 & 0.131 & $0.401 *$ & 0.067 & -0.166 & $-0.336^{*}$ & 0.007 & -0.148 & 0.003 \\
\hline Control: $0^{\circ}$ & $(0.161)$ & $(0.218)$ & $(0.185)$ & $(0.142)$ & $(0.235)$ & $(0.165)$ & $(0.194)$ & $(0.262)$ & $(0.034)$ \\
\hline Animal:1/ & 0.193 & 0.233 & 0.233 & 0.074 & -0.139 & -0.077 & 0.033 & 0.067 & 0.002 \\
\hline Control: $0^{\circ}$ & $(0.172)$ & $(0.222)$ & $(0.197)$ & $(0.133)$ & $(0.222)$ & $(0.155)$ & $(0.212)$ & $(0.247)$ & $(0.031)$ \\
\hline Climate:1/ & -0.058 & -0.098 & 0.146 & 0.024 & -0.007 & -0.248 & -0.023 & -0.180 & -0.012 \\
\hline Animal: $0^{\circ}$ & $(0.163)$ & $(0.223)$ & $(0.188)$ & $(0.140)$ & $(0.258)$ & $(0.187)$ & $(0.222)$ & $(0.286)$ & $(0.037)$ \\
\hline $\begin{array}{l}\text { Adjusted } \\
\mathrm{R}^{2}\end{array}$ & 0.087 & 0.055 & 0.167 & 0.049 & 0.215 & 0.220 & 0.163 & 0.107 & 0.005 \\
\hline \multicolumn{10}{|c|}{$\begin{array}{l}\text { Significance levels indicated by: } \bullet \mathrm{p} \leq 0.10 * \mathrm{p} \leq 0.05 * * \mathrm{p} \leq 0.01 * * * \mathrm{p} \leq 0.001 \\
\text { Standard error in parentheses } \\
\text { (climate problem, race, age, sex, education level, political leaning and distance were held as controls in this } \\
\text { model) } \\
{ }^{\circ} \text { Each treatment indicator variable was run independently with the controls, but listed together } \\
\text { for ease of presentation }\end{array}$} \\
\hline
\end{tabular}

The Republican subgroup was associated with highest support of policies and highest likelihood to engage in outcome behaviors when among the charismatic animal treatment group. The control frame was associated with the highest support for outcome variables among Independent/No party subgroup. The climate change frame and the control frame each were significantly associated with one outcome variable among Democrats. The full sample showed significant association from the control framing and the charismatic animal framing groups equally for policy support and likelihood to engage in behaviors.

\section{Subgroups}

The sample was also divided into for subgroup analysis. This was done because, as mentioned previously, literature shows that females have higher environmental concern than males. Table 9 shows the distribution of respondents among framing groups by. The sample was re-coded into male (39.1\%), 
female $(54.9 \%)$ and non-binary $(6.1 \%)$. There were statistically significant results between treatment groups among these sex subgroupings, illustrating that there is a difference between environmental concern and sex. The control framing was associated with the highest support of policy and behavior outcome variables within the male subgroup. Whereas the charismatic animal framing was significantly associated with the highest support of outcome variables within the female subgroup.

\begin{tabular}{|llll|}
\hline \multicolumn{4}{|c|}{ Table 9: Framing Group Distributions- Subgroups } \\
\hline & Control & Charismatic Animal & Climate Change \\
Female & 120 & 82 & 79 \\
Male & 69 & 63 & 68 \\
\hline
\end{tabular}

\section{Male-Identifying Subgroup}

The male-identifying subgroup was more impacted by the control frame compared to either of the treatment framings as shown in table 10; this is similar to the results from the full sample which also showed influence from the control group. Among males, receiving the control frame was associated with an $8.7 \%$ higher likelihood to engage in politically active behavior (politic) $(\mathrm{p}<0.05)$ over the climate frame. Receiving the control frame over the charismatic animal frame was associated with an $8.2 \%$ higher likelihood of politic $(\mathrm{p}<0.10)$ among males. There was no significance between the climate change and charismatic animal framings for politic among males. No other dependent variables were associated with statistical significance caused by different treatments among the male subgroup. 


\begin{tabular}{|c|c|c|c|c|c|c|c|c|c|}
\hline \multicolumn{10}{|c|}{ Table 10: Male-Identifying Subgroup OLS Regression Analysis } \\
\hline & Bag & Straw & Other & $E P R$ & Politic & Mod & Drastic & $\begin{array}{l}\text { Clean- } \\
\text { Up }\end{array}$ & Donate \\
\hline Climate:1/ & -0.232 & 0.164 & 0.018 & -0.212 & $-0.614 * *$ & -0.034 & -0.200 & -0.082 & 0.031 \\
\hline Control: $0^{\circ}$ & $(0.224)$ & $(0.263)$ & $(0.258)$ & $(0.238)$ & $(0.295)$ & $(0.226)$ & $(0.259)$ & $(0.288)$ & $(0.038)$ \\
\hline Animal:1/ & -0.173 & 0.280 & 0.044 & -0.200 & $-0.571 \bullet$ & 0.073 & -0.060 & -0.048 & 0.033 \\
\hline Control: $0^{\circ}$ & $(0.252)$ & $(0.271)$ & $(0.260)$ & $(0.230)$ & $(0.296)$ & $(0.238)$ & $(0.284)$ & $(0.309)$ & $(0.036)$ \\
\hline $\begin{array}{l}\text { Climate: } 1 / \\
\text { Animal: } 0^{\circ}\end{array}$ & $\begin{array}{l}-0.014 \\
(0.239)\end{array}$ & $\begin{array}{l}-0.110 \\
(0.248)\end{array}$ & $\begin{array}{l}-0.031 \\
(0.250)\end{array}$ & $\begin{array}{l}-0.026 \\
(0.244)\end{array}$ & $\begin{array}{l}-0.037 \\
(0.335)\end{array}$ & $\begin{array}{l}-0.066 \\
(0.244)\end{array}$ & $\begin{array}{l}-0.129 \\
(0.283)\end{array}$ & $\begin{array}{l}-0.049 \\
(0.334)\end{array}$ & $\begin{array}{l}0.006 \\
(0.041)\end{array}$ \\
\hline $\begin{array}{c}\text { Adjusted } \\
\mathrm{R}^{2}\end{array}$ & 0.324 & 0.281 & 0.312 & 0.234 & 0.248 & 0.326 & 0.233 & 0.158 & 0.231 \\
\hline \multicolumn{10}{|c|}{$\begin{array}{l}\text { Significance levels indicated by: } \bullet \mathrm{p} \leq 0.10 * \mathrm{p} \leq 0.05 * * \mathrm{p} \leq 0.01 * * * \mathrm{p} \leq 0.001 \\
\text { Standard error in parentheses } \\
\text { (climate problem, race, age, sex, education level, political leaning and distance were held as controls in this } \\
\text { model) } \\
{ }^{\circ} \text { Each treatment indicator variable was run independently with the controls, but listed together } \\
\text { for ease of presentation }\end{array}$} \\
\hline
\end{tabular}

Female-Identifying Subgroup

\begin{tabular}{|c|c|c|c|c|c|c|c|c|c|}
\hline \multicolumn{10}{|c|}{ Table 11: Female Subgroup OLS Regression Results } \\
\hline & Bag & Straw & Other & $E P R$ & Politic & Mod. & Drastic & $\begin{array}{l}\text { Clean- } \\
\text { Up }\end{array}$ & Donate \\
\hline $\begin{array}{l}\text { Climate: } 1 / \\
\text { Control:0 }\end{array}$ & $\begin{array}{l}-0.125 \\
(0.197)\end{array}$ & $\begin{array}{l}-0.162 \\
(0.251)\end{array}$ & $\begin{array}{l}-0.210 \\
(0.210)\end{array}$ & $\begin{array}{l}-0.132 \\
(0.167)\end{array}$ & $\begin{array}{l}-0.092 \\
(0.240)\end{array}$ & $\begin{array}{l}-0.233 \\
(0.168)\end{array}$ & $\begin{array}{l}-0.012 \\
(0.201)\end{array}$ & $\begin{array}{l}0.013 \\
(0.276)\end{array}$ & $\begin{array}{l}-0.008 \\
(0.036)\end{array}$ \\
\hline $\begin{array}{l}\text { Animal:1/ } \\
\text { Control:0º }\end{array}$ & $\begin{array}{l}0.370 * \\
(0.184)\end{array}$ & $\begin{array}{l}0.438 \bullet \\
(0.242)\end{array}$ & $\begin{array}{l}0.240 \\
(0.209)\end{array}$ & $\begin{array}{l}-0.004 \\
(0.163)\end{array}$ & $\begin{array}{l}-0.116 \\
(0.227)\end{array}$ & $\begin{array}{l}-0.011 \\
(0.170)\end{array}$ & $\begin{array}{l}-0.018 \\
(0.217)\end{array}$ & $\begin{array}{l}0.131 \\
(0.270)\end{array}$ & $\begin{array}{l}0.037 \\
(0.035)\end{array}$ \\
\hline $\begin{array}{l}\text { Climate: } 1 \\
\text { Animal:0 }\end{array}$ & $\begin{array}{l}-0.488^{*} \\
(0.214)\end{array}$ & $\begin{array}{l}-0.662 * \\
(0.270)\end{array}$ & $\begin{array}{l}-0.447 \bullet \\
(0.229)\end{array}$ & $\begin{array}{l}-0.075 \\
(0.178)\end{array}$ & $\begin{array}{l}0.022 \\
(0.276)\end{array}$ & $\begin{array}{l}-0.220 \\
(0.198)\end{array}$ & $\begin{array}{l}0.022 \\
(0.228)\end{array}$ & $\begin{array}{l}-0.167 \\
(0.299)\end{array}$ & $\begin{array}{l}-0.046 \\
(0.040)\end{array}$ \\
\hline Adjusted $\mathrm{R}^{2}$ & ${ }^{2} 0.219$ & 0.121 & 0.226 & 0.195 & 0.261 & 0.257 & 0.213 & 0.128 & 0.052 \\
\hline \multicolumn{10}{|c|}{$\begin{array}{l}\text { Significance levels indicated by: } \bullet \mathrm{p} \leq 0.10 * \mathrm{p} \leq 0.05 * * \mathrm{p} \leq 0.01 * * * \mathrm{p} \leq 0.001 \\
\text { Standard error in parentheses } \\
\text { (climate problem, race, age, sex, education level, political leaning and distance were held as controls in this model) } \\
{ }^{\circ} \text { Each treatment indicator variable run independently with the controls, but listed together for ease } \\
\text { of presentation }\end{array}$} \\
\hline
\end{tabular}

The female respondents were more impacted by the charismatic animal framing than

by the control or climate change framing. This is slightly different than the results seen among the full sample, which saw significance from the control framing, but is similar to the trend seen among the Republican subgroup (highest association from 
charismatic animal frame). The charismatic animal frame was associated with a $6.3 \%$ higher support for a plastic bag ban compared to the control group $(\mathrm{p}<0.05)$ and a 7.0\% higher support compared to the climate change frame $(\mathrm{p}<0.05)$ among females. As shown in table 11, there was no significant difference between the control group and the climate change group among females for bag. The charismatic animal frame was also associated with a $6.3 \%$ higher support of a straw ban compared to the control frame $(\mathrm{p}<0.10)$ and $9.5 \%$ higher support compared to the climate frame $(\mathrm{p}<0.05)$ among females. There was no significant difference in support of straw between the climate change frame and the control framing among females.

The subgroups showed important differences. The male subgroup was overall more influenced by the control framing. The female subgroup was more influenced by the charismatic animal framing. This does not reveal a trend that one of the sexes in this sample has more concern for environmental problems but does reveal important differences in how each sex responds to environmental framing messages. 


\section{CHAPTER 5}

\section{DISCUSSION}

The full sample provided evidence supporting the effectiveness of the control framing, as well as the charismatic animal framing, particularly for policy support (straw, bag). While these results do not support the hypothesis (that the climate change frame would be associated with the highest support), affirmation of the control and charismatic animal framings being impactful allow us to draw meaningful conclusions from the experiment. The control framing being associated with significantly higher policy support may suggest that simply describing plastic pollution as an environmental problem may be sufficient to increase support for policies and reduction behaviors among most Americans. These results also indicates that adding extra information (climate change or charismatic animal) may detract from policy and behavior support for plastic reduction, because the added information may bring up other associations, such as political identity, which are stronger determinants of support for policy and/or behavior change. The results from the charismatic animal framing (high significance for single-use straw and bag bans) illustrates that connecting bans of single-use straws and bags to the well-being of turtles or other wildlife can be a good tool for these specific policies. If we want to continue trying to implement straw and bag bans, framing the detrimental impact of plastic waste to the survival and/or health of animals is an effective method of communication to the general American public. If we want to pursue larger policies, such as extended producer responsibility (EPR), discussion about plastic more generally is suitable. 
When the sample was separated into political and sex subgroups, results were further elucidated. Respondents who indicated their political affiliation as Independent were most influenced by the control framing. This result illustrates that basic information about plastic pollution may be enough to elicit support of plastic reduction policies in those that do not possess strong political affiliations for one specific political party. Furthermore, the results among Independent/No Party affiliates illustrate that strong political ideologies may have informed the responses among Democrats and Republicans. The Democrats subgroup only had significance of two outcome variables associated with treatment group: one from the climate change framing and one from the control framing. This is likely because Democrats tend to already be supportive of environmental policy and action. Democrats had high levels of support for all the policies and behavior, and therefore were not swayed much by framing messages. Democrats made up the majority of the sample, which is likely also why there were not overwhelmingly significant differences in treatment conditions among the full sample.

When viewed independent of the Democrat and Independent responses, Republicans were more positively impacted by the charismatic animal framing compared to both the control and the climate change framings. This is likely because Republicans associate their party as being against climate change policy, and that identity may have influenced survey results. The results from this subgrouping show that Republicans were supportive of policies for reducing plastic production, consumption and therefore pollution; but not when it was connected to climate change. Therefore, if communication is targeted directly to Republican voters, using the 
charismatic animal frame may be most effective for gaining widespread policy support.

The sex subgroupings also revealed important results. The charismatic animal frame was associated with higher support of plastic reduction policies and higher likelihood to engage in personal behaviors targeted at plastic pollution, compared to the climate or control framings among females. The control framing was associated with higher support for outcome variables compared to either treatment group among males. The male subgroup results were similar to the full sample and the Independent/No Party subgroup, meaning that receiving additional information about plastic (climate change or charismatic animal) reduced male support of policies and likelihood to engage in personal plastic behaviors. This aligns with literature that females have higher concern for animals (Angantyr, Eklund \& Hansen 2015) and were therefore more impacted by the charismatic animal frame compared to the climate or control framings. Males have been shown to have a more equal level of empathy for humans and animals (Angantyr, Eklund \& Hansen 2015), and therefore the results that the control framing was most significantly associated with outcome variables aligns with current literature. Additionally, if communication is known to be to a specific sex grouping, the framing of plastic pollution can be changed to facilitate stronger policy support for differing plastic reduction policies.

This study represents the first framing study of its kind to look at framing effects of plastic pollution messaging and how it influences policy support. Therefore, there is a lot to be built on for research in the future. Studies in the past have shown that different framing messages with images can evoke emotion, but these emotions 
were not always tied to policy support. "Climate change" may have been a trigger word for a lot of people (especially the Republicans) that influenced a lot of prior held beliefs and attitudes to come to the forefront. This is likely why this study showed mixed results, and why the control framing was statistically more impactful in many scenarios. This illustrates that this sample was generally supportive of action on plastic pollution, but that these may not be the best communication frames. Plastic production and pollution affect many different facets of everyday life and all these framing possibilities should be investigated. Plastic's impact on human health, soil or water quality, or environmental justice framings are all frames that should be tested to assess their influence over policy support.

\section{Limitations and Recommendations}

This study did have limitations, the main one being the cost of paying participants. I wanted to stray away from using a college sample, due to the skewed nature of the demographics, as well as the time it would take to gain all the data. So, I used the online paid platform. This however limited me to the number of participants I could use, and a larger sample would have led to better results. Given more resources and time, I would repeat this survey with a much larger number of participants, with more treatment groups. The participants also self-select to take part in the survey, and therefore may have introduced bias in who decided to participate.

Additionally, the sample differed from the general U.S. population in important ways that may have impacted the results. This sample was majority younger people (below 35) and therefore has an age skew, even though I tried to avoid one. There is evidence that younger people tend to be more supportive of environmental 
policies (Mueller \& Mullenbach 2018) and is therefore also part of the reason that this sample had high levels of support on plastic pollution action. The sample was majority Democrats (57\%), and liberal (65\%). Political affiliation is a strong indicator of environmental support, with Democrats and liberals showing much higher concern for environmental problems (Cruz 2017). This therefore had an impact on the results because this group was already highly supportive of action on plastic pollution. A large majority of the sample was white (67\%) and $73 \%$ of the sample had some college or a bachelor's degree. It is important to make note of these skewed demographics, because they are higher proportions than the American population; however, it does not hinder the ability to draw conclusions from this study.

The number of participants that had to be excluded for failing the attention checks also caused issues with sample size. If I were to run the experiment again, I would also include a feature in the survey that if the respondents answered the treatment check incorrectly, it would bounce them back to re-read it and answer the prompt again. Furthermore, the control group was not given a treatment check question and therefore respondents were only removed from both treatment groups. Given the difference between sexes and political parties shown in this study, there is likely not one "best" frame for plastic pollution; but a larger sample, with multiple frames would give a better picture of how to best frame and communicate plastic pollution to solve the plastic pollution problem. I would also make the survey longer and ask more detailed questions to better understand the way respondents think about plastic policies. 
The wording for my treatment check may have been confusing given the large proportion of people that answered incorrectly (20\%). It is possible the question, or the paragraph was confusing to respondents so given the time and resources, I would conduct a focus group to identify misunderstandings prior to survey publication to improve the data collection.

It is also important to note the fact that this study was conducted during the winter of 2020. The United States was seeing peak rates of coronavirus deaths and cases, and major cities were reinstating restrictions they had previously lifted in the summer and fall. The United States was coming off an intense election, where former president Donald Trump was claiming fraud, and political identities were on the forefront of people's minds. Pandemic caused unemployment was decreasing but still at record highs. This is all to say that the environment, and plastic pollution may not be the most pressing issue for a lot of Americans, and many of the people responding to surveys on Prolific. While the results show there is general concern and care over plastic pollution, it is important to remember the political and social context of the time because it may have tempered the results. 


\section{APPENDICES}

Survey

What is your prolific ID?

1. To what degree do you agree or disagree with the following statement: I believe climate change is caused by human actions.
a. Strongly agree
b. Agree
c. Neutral
d. Disagree
e. Strongly disagree

\section{Participants then received the frames here}

1. What was the topic of the paragraph from the previous page? *answer will vary based on frame, only the 2 treatment groups will receive this question*
a. The human health impacts of plastic pollution
b. How much plastic a sea turtle consumes
c. The relationship of plastic production to emissions causing climate change
d. The yearly cost of cleaning plastic pollution

\section{The question below will appear randomly throughout the survey}

2. If you are following along please choose B
a. A
b. B
c. C
d. D
e. E

\section{Survey Questions}

1. To what degree would you oppose or support a plastic straw ban, which would make it illegal for restaurants to supply plastic straws with drinks?
- Strongly oppose
○ Oppose
- Somewhat oppose
- Neutral
- Somewhat support
- Support
○ Strongly support

2. To what degree would you oppose or support a plastic bag ban, which would make it illegal for stores to give out plastic bags with purchases?
○ Strongly Oppose
- Oppose
- Somewhat oppose
- Neutral 

○ Somewhat support
○ Support
○ Strongly support

3. To what degree would you oppose or support other single use plastic bans, making it illegal to sell other single use plastic items such as single use water bottles or singleuse utensils?
○ Strongly oppose
○ Oppose
○ Somewhat oppose
- Neutral
- Somewhat support
○ Support
○ Strongly support

4. To what degree would you oppose or support extended producer responsibility which puts the cost of plastic on the producer instead of society? For example, making Coca Cola responsible for recycling of all plastic bottles they produce.
- Strongly oppose
- Oppose
- Somewhat oppose
- Neutral
- Somewhat support
- Support
○ Strongly support

5. How often do you think about your personal use of single-use plastics?
○ Every day
- Once a week
- A few times a month
- Once a month
- A few times a year
○ Never

6. How likely or unlikely are you to do any of the following in the next month to help to reduce marine plastic pollution?

a. Become more politically involved on the issue of plastics pollution (voting for representatives that advocate reducing marine plastic pollution, signing petitions)
○ Extremely unlikely
○ Unlikely
- Somewhat unlikely
- Neither likely nor unlikely
○ Somewhat likely
○ Likely
○ Extremely likely 
b. Moderately reduce your personal plastic use (not use single use straws, bring a reusable coffee mug to the coffee shop, bring reusable bags to the grocery store)

- Extremely unlikely

○ Unlikely

- Somewhat unlikely

○ Neither likely nor unlikely

○ Somewhat likely

○ Likely

- Extremely likely

c. Drastically reduce your personal plastic use (buy groceries from bulk stores, use toiletries packaged in alternative ways)

○ Extremely unlikely

○ Unlikely

- Somewhat unlikely

- Neither likely nor unlikely

- Somewhat likely

○ Likely

- Extremely likely

d. Attend or organize a local beach clean-up

- Extremely unlikely

○ Unlikely

- Somewhat unlikely

- Neither likely nor unlikely

- Somewhat likely

○ Likely

○ Extremely likely

7. To what degree do you agree or disagree with the following statement: I believe marine plastic pollution is a problem.

○ Strongly agree

○ Agree

○ Neutral

- Disagree

○ Strongly disagree

8. Has the global COVID-19 pandemic changed your perspective on single-use plastics?
○ Not at all
○ Some
- I have not previously considered it
- A moderate amount
○ A lot 
9. Do you consider yourself to be politically liberal, politically conservative or neither?
- Very liberal
- Moderately liberal
- Neither liberal nor conservative
○ Moderately conservative
○ Very conservative

10. Are you willing to donate all or some of your payment for taking part in this survey to 5Gyres, a nonprofit organization that fights plastic pollution?

Sliding scale from $\$ 0.00$ to $\$ 0.66$

\section{Demographics}

1. What is your age?
○ $18-24$
○ $25-34$
○ $35-44$
○ $45-54$
○ $55-64$
○ 65 and over

2. What is your race?
○ White/Caucasian
- Hispanic or Latino
- Black or African American
- Native American or American Indian
- Asian/ Pacific Islander
O Other
- Prefer not to answer

3. What is the highest level of education you have achieved?
$\circ$ High school or diploma
- Some college
- Bachelor's degree
- Masters degree
- Doctorate

4.To which voting party do you most identify?
- Republican
○ Democrat
Independent
○ None of the above

5. How close do you live to the ocean?

$$
\text { ○ 0-5 miles }
$$


- 6-10 miles

- 11-30 miles

- 31-50 miles

- 51-100 miles

- More than 100 miles 
Treatment Group: Renamed "Group \#”

Climate: $1 \quad$ Turtle: $2 \quad$ Control: 3

To what degree do you agree or disagree with the following statement: I believe marine plastic pollution is a problem. Renamed "PlasticProb\#"

Strongly Disagree: 1 Disagree: 2 Neither agree nor Agree: 4 disagree: 3

Strongly Agree: 5

How often do you think about your personal use of single-use plastics? Renamed "Think\#"

Never: 1 A few times a year: Once a month: 3 A few times

Once a week: $5 \quad$ Every day: 6

a month: 4

To what degree do you agree or disagree with the following statement: I believe climate change is caused by human actions. Renamed "ClimateProb\#"

Strongly Disagree: 1 Disagree: 2 Neither agree nor Agree: 4

Strongly Agree: 5

disagree: 3

To what degree would you oppose or support a plastic bag ban, which would make it illegal for stores to give out plastic bags with purchases? Renamed "BagBan\#"

Strongly Oppose: 1 Oppose: $2 \quad$ Somewhat Oppose: 3 Neutral: 4

Somewhat Support: Support: $6 \quad$ Strongly Support: 7

5

To what degree would you oppose or support a plastic straw ban, which would make it illegal for restaurants to supply plastic straws with drinks? Renamed "StrawBan\#"

Strongly Oppose: $1 \quad$ Oppose: $2 \quad$ Somewhat Oppose: 3 Neutral: 4

Somewhat Support: Support: $6 \quad$ Strongly Support: 7

5

To what degree would you oppose or support extended producer responsibility which puts the cost of plastic on the producer instead of society? For example, making Coca Cola responsible for recycling of all plastic bottles they produce. Renamed "Producer\#"

Strongly Oppose: 1 Oppose: $2 \quad$ Somewhat Oppose: 3 Neutral: 4 Somewhat Support: Support: $6 \quad$ Strongly Support: 7 5 
To what degree would you oppose or support other single use plastic bans, making it illegal to sell other single use plastic items such as single use water bottles or single-use utensils? Renamed "OtherBan\#"

Strongly Oppose: 1 Oppose: $2 \quad$ Somewhat Oppose: 3 Neutral: 4 Somewhat Support: Support: $6 \quad$ Strongly Support: 7

5

How likely or unlikely are you to do any of the following in the next month to help to reduce marine plastic pollution? Become more politically involved on the issue of plastics pollution (voting for representatives that advocate reducing marine plastic pollution, signing petitions). Renamed "Politic\#"

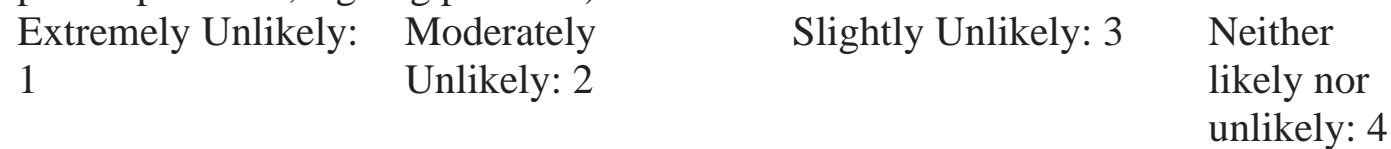

Slightly Likely: 5 Moderately Likely: Extremely Likely: 7 6

How likely or unlikely are you to do any of the following in the next month to help to reduce marine plastic pollution? Moderately reduce your personal plastic use (not use single use straws, bring a reusable coffee mug to the coffee shop, bring reusable bags to the grocery store). Renamed "Moderate\#"

Extremely Unlikely: Moderately Slightly Unlikely: 3 Neither 1 Unlikely: 2 likely nor

Slightly Likely: 5 Moderately Likely: Extremely Likely: 7 unlikely: 4 6

How likely or unlikely are you to do any of the following in the next month to help to reduce marine plastic pollution? Drastically reduce your personal plastic use (buy groceries from bulk stores, use toiletries packaged in alternative ways). Renamed "Drastic\#"

Extremely Unlikely: Moderately Slightly Unlikely: 3 Neither 1 Unlikely: 2 likely nor

Slightly Likely: $5 \quad$ Moderately Likely: Extremely Likely: 7 unlikely: 4 6

How likely or unlikely are you to do any of the following in the next month to help to reduce marine plastic pollution? Attend or organize a local beach clean-up. Renamed "CleanUp\#" Extremely Unlikely: Moderately 1 Unlikely: 2 Slightly Unlikely: 3 Neither

Slightly Likely: $5 \quad$ Moderately Likely: Extremely Likely: 7 likely nor unlikely: 4 6

How close do you live to the ocean? Renamed "Distance\#"

0-5 Miles: 1 6-10 Miles: 2 11-30 Miles: 3

$31-50$

Miles: 4 
51-100 Miles: $5 \quad$ More than 100

Miles: 6

Do you consider yourself to be politically liberal, politically conservative or neither? Renamed "Leaning\#"

Very Conservative: Moderately Neither Liberal nor Moderately

1 Conservative: 2 Conservative: $3 \quad$ Liberal: 4

Very Liberal: 5

Has the global COVID-19 pandemic changed your perspective on single-use plastics? Renamed "COVID\#"

Not at all $1 \quad$ Some: $2 \quad$ I have not previously A moderate considered it: $3 \quad$ amount: 4

A lot: 5

To which voting party do you most identify? Renamed "Party\#"

Republican: 1 Independent: 2 Democrat: 3 None of the

Above: 4

What is the highest level of education you have achieved? Renamed "EdLevel\#"

High school or Some college: 2 Bachelor's degree: 3 Masters

diploma: 1

degree: 4

Doctorate: 5

What is your age? Renamed "AgeRange"

18-24: $1 \quad$ 25-34: 2 35-44: 3 45-54: 4

55-64: $5 \quad 65$ and over: 6

What is your race? Renamed "Race\#"

White or Caucasian: Hispanic or Latino: Black or African Native

$1 \quad 2$ American: 3 American

or

American

Indian: 4

Asian or Pacific Other: $6 \quad$ Prefer not to answer:

Islander: 5

7

What is your sex identity? Renamed "Sex \#"

Male: 1

Female: 2

Queer/Gender Non-

Transgender

Other: 5

Conforming: 3

Male: 4

Did the participant correctly answer the treatment check question? Named

"CorrectCheck"

Yes: 1

No: 0 


\section{OLogit Full Sample Results}

\begin{tabular}{|c|c|c|c|c|c|c|c|c|c|}
\hline \multicolumn{10}{|c|}{ Full Sample Ordered Logit Regression Results } \\
\hline \multicolumn{10}{|c|}{ Outcome Variables } \\
\hline & Bag & Straw & $E P R$ & Other & Politic & Moderate & Drastic & Clean-Up & Donate \\
\hline \multirow[t]{2}{*}{ Climate: 1} & -0.222 & -0.050 & -0.163 & 0.033 & -0.093 & -0.152 & -0.108 & 0.024 & -0.160 \\
\hline & $(0.216)$ & $(0.212)$ & $(0.238)$ & $(0.211)$ & $(0.209)$ & $(0.218)$ & $(0.211)$ & $(0.213)$ & $(0.228)$ \\
\hline \multirow[t]{2}{*}{ Animal: 2} & $0.472 * *$ & $0.463^{* *}$ & 0.099 & 0.333 & -0.283 & 0.219 & 0.053 & -0.001 & 0.216 \\
\hline & $(0.225)$ & $(0.218)$ & $(0.244)$ & $(0.214)$ & $(0.213)$ & $(0.222)$ & $(0.213)$ & $(0.215)$ & $(0.226)$ \\
\hline \multirow[t]{2}{*}{ [ClimateProb\#=1] } & 0.426 & 0.051 & -0.546 & $-2.562^{*}$ & -1.791 & -0.310 & -1.310 & -1.173 & -0.516 \\
\hline & $(1.192)$ & $(1.154)$ & $(1.175)$ & $(1.222)$ & (1.175) & (1.173) & $(0.151)$ & $(1.384)$ & (1.145) \\
\hline \multirow[t]{2}{*}{ [ClimateProb\#=2] } & $-1.842 * * *$ & $-0.924 \bullet$ & -0.198 & $-1.751 * * *$ & -0.360 & -0.129 & $-1.000 \bullet$ & 0.295 & $-0.97 \bullet$ \\
\hline & $(0.532)$ & $(0.524)$ & $(0.565)$ & $(0.527)$ & $(0.535)$ & $(0.535)$ & $(0.527)$ & $(0.562)$ & $(0.592)$ \\
\hline \multirow[t]{2}{*}{ [ClimateProb\#=3] } & $-1.606^{* * *}$ & $-1.330^{* *}$ & $-1.439 * *$ & $-1.356^{* *}$ & -0.150 & $-0.825 \bullet$ & $-1.177 * *$ & -0.096 & $-0.828 \bullet$ \\
\hline & $(0.463)$ & $(0.458)$ & $(0.474)$ & $(0.456)$ & $(0.454)$ & $(0.466)$ & $(0.458)$ & $(0.467)$ & $(0.484)$ \\
\hline \multirow[t]{2}{*}{ [ClimateProb\#=4] } & $-0.551 * *$ & $-0.407 *$ & $-1.013 * * *$ & $-0.404 \bullet$ & -0.330 & $-0.440 *$ & $-0.408^{*}$ & 0.146 & -0.174 \\
\hline & $(0.215)$ & $(0.211)$ & $(0.233)$ & $(0.209)$ & $(0.206)$ & $(0.215)$ & $(0.208)$ & $(0.207)$ & $(0.209)$ \\
\hline \multirow[t]{2}{*}{ [Distance\#=1] } & 0.392 & -0.224 & $0.713 \bullet$ & -0.127 & -0.083 & 0.222 & 0.366 & 0.118 & -0.348 \\
\hline & $(0.310)$ & $(0.295)$ & $(0.368)$ & $(0.295)$ & $(0.292)$ & $(0.309)$ & $(0.294)$ & $(0.297)$ & $(0.313)$ \\
\hline \multirow[t]{2}{*}{ [Distance\#=2] } & 0.634 & $0.889 * *$ & 0.617 & $0.650^{\bullet}$ & 0.623 & 0.230 & $0.926^{* *}$ & $1.099 * *$ & 0.381 \\
\hline & $(0.411)$ & $(0.408)$ & $(0.454)$ & $(0.395)$ & $(0.383)$ & $(0.399)$ & $(0.394)$ & $(0.385)$ & $(0.405)$ \\
\hline \multirow[t]{2}{*}{ [Distance\#=3] } & $0.850^{* *}$ & $0.632 * *$ & $0.856^{* *}$ & $0.474 \bullet$ & $0.474 \bullet$ & $0.730 * *$ & 0.405 & $1.004 * * *$ & -0.364 \\
\hline & $(0.296)$ & $(0.286)$ & $(0.328)$ & $(0.280)$ & $(0.277)$ & $(0.295)$ & $(0.278)$ & $(0.279)$ & $(0.302)$ \\
\hline \multirow[t]{2}{*}{ [Distance\#=4] } & $0.618 \bullet$ & 0.175 & 0.397 & -0.047 & 0.227 & 0.403 & 0.099 & -0.006 & -0.281 \\
\hline & $(0.348)$ & $(0.332)$ & $(0.373)$ & $(0.329)$ & $(0.326)$ & $(0.344)$ & $(0.328)$ & $(0.329)$ & $(0.344)$ \\
\hline \multirow[t]{2}{*}{ [Distance\#=5] } & 0.403 & $0.532 \bullet$ & 0.375 & -0.214 & 0.419 & 0.318 & $0.632 *$ & 0.033 & -0.227 \\
\hline & $(0.317)$ & $(0.312)$ & $(0.351)$ & $(0.306)$ & $(0.304)$ & $(0.319)$ & $(0.308)$ & $(0.309)$ & $(0.336)$ \\
\hline \multirow[t]{2}{*}{ [Leaning\#=1] } & -0.808 & -0.217 & $-1.900 * *$ & -0.659 & $-1.343 * *$ & $-1.720 * *$ & 0.098 & -0.973 & -0.497 \\
\hline & $(0.647)$ & $(0.643)$ & $(0.669)$ & $(0.637)$ & $(0.646)$ & $(0.655)$ & $(0.642)$ & $(0.695)$ & $(0.678)$ \\
\hline \multirow[t]{2}{*}{ [Leaning\#=2] } & -0.687 & -0.481 & $-1.722 * *$ & $-0.976^{*}$ & $-1.350 * *$ & $-0.922 \bullet$ & 0.321 & 0.345 & -0.102 \\
\hline & $(0.473$ & $(0.466)$ & $(0.501)$ & $(0.461)$ & $(0.462)$ & $(0.479)$ & $(0.462)$ & $(0.463)$ & $(0.477)$ \\
\hline \multirow[t]{2}{*}{ [Leaning\#=3] } & -0.199 & $0.587 \bullet$ & $-1.014 * *$ & 0.113 & $-1.354 * * *$ & -0.539 & 0.308 & 0.368 & -0.240 \\
\hline & $(0.343)$ & $(0.338)$ & $(0.384)$ & $(0.333)$ & $(0.333)$ & $(0.346)$ & $(0.330)$ & $(0.336)$ & $(0.359)$ \\
\hline
\end{tabular}




\section{REFERENCES}

Andelman, S. J., \& Fagan, W. F. (2000). Umbrellas and flagships: Efficient conservation surrogates or expensive mistakes? Proceedings of the National Academy of Sciences, 97(11), 5954-5959. https://doi.org/10.1073/pnas.100126797

Andrady, A. L. (2011). Microplastics in the marine environment. Marine Pollution Bulletin, 62(8), 1596-1605. https://doi.org/10.1016/j.marpolbul.2011.05.030

Angantyr, M., Eklund, J., \& Hansen, E. M. (2011). A Comparison of Empathy for Humans and Empathy for Animals. Anthrozoös, 24(4), 369-377. https://doi.org/10.2752/175303711X13159027359764

Anspach, N. M., \& Draguljić, G. (2019). Effective advocacy: The psychological mechanisms of environmental issue framing. Environmental Politics, 28(4), 615-638. https://doi.org/10.1080/09644016.2019.1565468

Baek, T. H., \& Yoon, S. (2017). Guilt and Shame: Environmental Message Framing Effects. Journal of Advertising, 46(3), 440-453. https://doi.org/10.1080/00913367.2017.1321069

Barua, M., Root-Bernstein, M., Ladle, R. J., \& Jepson, P. (2011). Defining Flagship Uses is Critical for Flagship Selection: A Critique of the IUCN Climate Change Flagship Fleet. Ambio, 40(4), 431-435. https://doi.org/10.1007/s13280-010-0116-2

Baulch, S., \& Perry, C. (2014). Evaluating the impacts of marine debris on cetaceans. Marine Pollution Bulletin, 80(1), 210-221. https://doi.org/10.1016/j.marpolbul.2013.12.050

Beaumont, N. J., Aanesen, M., Austen, M. C., Börger, T., Clark, J. R., Cole, M., Hooper, T., Lindeque, P. K., Pascoe, C., \& Wyles, K. J. (2019). Global ecological, social and 
economic impacts of marine plastic. Marine Pollution Bulletin, 142, 189-195. https://doi.org/10.1016/j.marpolbul.2019.03.022

Born, D. (2019). Bearing Witness? Polar Bears as Icons for Climate Change Communication in National Geographic. Environmental Communication, 13(5), 649663. https://doi.org/10.1080/17524032.2018.1435557

Chiba, S., Saito, H., Fletcher, R., Yogi, T., Kayo, M., Miyagi, S., Ogido, M., \& Fujikura, K. (2018). Human footprint in the abyss: 30-year records of deep-sea plastic debris. Marine Policy, 96, 204-212. https://doi.org/10.1016/j.marpol.2018.03.022

Chong, D., \& Druckman, J. N. (2007). Framing Theory. Annual Review of Political Science, 10(1), 103-126. https://doi.org/10.1146/annurev.polisci.10.072805.103054

Clayton, S., Koehn, A., \& Grover, E. (2013). Making Sense of the Senseless: Identity, Justice, and the Framing of Environmental Crises. Social Justice Research, 26(3), 301-319. https://doi.org/10.1007/s11211-013-0185-z

Courchamp, F., Jaric, I., Albert, C., Meinard, Y., Ripple, W. J., \& Chapron, G. (2018). The paradoxical extinction of the most charismatic animals. PLOS Biology, 16(4), e2003997. https://doi.org/10.1371/journal.pbio.2003997

Colléony, A., Clayton, S., Couvet, D., Saint Jalme, M., \& Prévot, A.-C. (2017). Human preferences for species conservation: Animal charisma trumps endangered status. Biological Conservation, 206, 263-269. https://doi.org/10.1016/j.biocon.2016.11.035

Cruz, S. M. (2017). The relationships of political ideology and party affiliation with environmental concern: A meta-analysis. Journal of Environmental Psychology, 53, 81-91. https://doi.org/10.1016/j.jenvp.2017.06.010 
Davis, J. J. (1995). The Effects of Message Framing on Response to Environmental Communications. Journalism \& Mass Communication Quarterly, 72(2), 285-299. https://doi.org/10.1177/107769909507200203

De Martino, B. (2006). Frames, Biases, and Rational Decision-Making in the Human Brain. Science, 313(5787), 684-687. https://doi.org/10.1126/science.1128356

Derraik, J. G. B. (2002). The pollution of the marine environment by plastic debris: A review. Marine Pollution Bulletin, 44(9), 842-852. https://doi.org/10.1016/S0025$326 X(02) 00220-5$

Dietz, T., Dan, A., \& Shwom, R. (2007). Support for Climate Change Policy: Social Psychological and Social Structural Influences*. Rural Sociology, 72(2), 185-214. https://doi.org/10.1526/003601107781170026

Dilkes-Hoffman, L. S., Pratt, S., Laycock, B., Ashworth, P., \& Lant, P. A. (2019). Public attitudes towards plastics. Resources, Conservation and Recycling, 147, 227-235. https://doi.org/10.1016/j.resconrec.2019.05.005

Druckman, J. N. (2001). The Implications of Framing Effects for Citizen Competence. Political Behavior, 23(3), 225-256. JSTOR.

Eriksen, M., Lebreton, L. C. M., Carson, H. S., Thiel, M., Moore, C. J., Borerro, J. C., Galgani, F., Ryan, P. G., \& Reisser, J. (2014). Plastic Pollution in the World's Oceans: More than 5 Trillion Plastic Pieces Weighing over 250,000 Tons Afloat at Sea. PLOS ONE, 9(12), e111913. https://doi.org/10.1371/journal.pone.0111913

Frazier, J. G. (2005). Marine Turtles: The Role of Flagship Species in Interactions Between People and the Sea. http://repository.si.edu/xmlui/handle/10088/4043 
Goldberg, E. D. (1994). Diamonds and plastics are forever? Marine Pollution Bulletin, 28(8), 466. https://doi.org/10.1016/0025-326X(94)90511-8

Gregory, M. R. (2009). Environmental implications of plastic debris in marine settingsEntanglement, ingestion, smothering, hangers-on, hitch-hiking and alien invasions. Philosophical Transactions of the Royal Society B: Biological Sciences, 364(1526), 2013-2025. https://doi.org/10.1098/rstb.2008.0265

Guo, X., Sun, X., Chen, Y., Hou, L., Liu, M., \& Yang, Y. (2020). Antibiotic resistance genes in biofilms on plastic wastes in an estuarine environment. Science of The Total Environment, 745, 140916. https://doi.org/10.1016/j.scitotenv.2020.140916

Hamilton, L, A., Feit, S., Muffett, C., Kelso, M., Rubright, S, M., Bernhardt, C., Schaeffer, E., Moon, D., Morris, J., Labbe-Bellas, R. (2019) Plastic \& Climate: The Hidden Costs of a Plastic Planet. Retrieved April 7, 2020, from https://www.ciel.org/wpcontent/uploads/2019/05/Plastic-and Climate-FINAL-2019.pdf

Hausmann, A., Slotow, R., Fraser, I., \& Minin, E. D. (2017). Ecotourism marketing alternative to charismatic megafauna can also support biodiversity conservation. Animal Conservation, 20(1), 91-100. https://doi.org/10.1111/acv.12292

Henderson, L., \& Green, C. (2020). Making sense of microplastics? Public understandings of plastic pollution. Marine Pollution Bulletin, 152, 110908. https://doi.org/10.1016/j.marpolbul.2020.110908

Heywood, V. H., \& Watson, R. T. (1995). Global biodiversity assessment (Vol. 1140). Cambridge: Cambridge university press. 
Jambeck, J. R., Geyer, R., Wilcox, C., Siegler, T. R., Perryman, M., Andrady, A., Narayan, R., \& Law, K. L. (2015). Plastic waste inputs from land into the ocean. Science, 347(6223), 768-771. https://doi.org/10.1126/science.1260352

Jang, Y. C., Hong, S., Lee, J., Lee, M. J., \& Shim, W. J. (2014). Estimation of lost tourism revenue in Geoje Island from the 2011 marine debris pollution event in South Korea. Marine Pollution Bulletin, 81(1), 49-54. https://doi.org/10.1016/j.marpolbul.2014.02.021

Lakoff, G. (2010). Why it Matters How We Frame the Environment. Environmental Communication, 4(1), 70-81. https://doi.org/10.1080/17524030903529749

Lamb, J. B., Willis, B. L., Fiorenza, E. A., Couch, C. S., Howard, R., Rader, D. N., True, J. D., Kelly, L. A., Ahmad, A., Jompa, J., \& Harvell, C. D. (2018). Plastic waste associated with disease on coral reefs. Science, 359(6374), 460-462. https://doi.org/10.1126/science.aar3320

Mæland, C. E., \& Staupe-Delgado, R. (2019). Can the Global Problem of Marine Litter Be Considered a Crisis? Risk, Hazards \& Crisis in Public Policy, 00(00). https://doi.org/10.1002/rhc3.12180

Manzo, K. (2010). Beyond polar bears? Re-envisioning climate change. Meteorological Applications, 17(2), 196-208. https://doi.org/10.1002/met.193

Matthes, J. (2008). Media Frames and Political Judgements. Exploring the Boundaries of Framing Effects in a Two-Wave Panel Study. https://doi.org/10.5167/uzh-14296

Mayer, A. (2017). Political identity and paradox in oil and gas policy: A study of regulatory exaggeration in Colorado, US. Energy Policy, 109, 452-459. https://doi.org/10.1016/j.enpol.2017.07.023 
Morrissey, K. (2019). Aligning Ocean Plastic Pollution and Human Health a Co-benefits Approach. Journal of Ocean and Coastal Economics, 6(1). https://doi.org/10.15351/2373-8456.1090

Mueller, J. T., \& Mullenbach, L. E. (2018). Looking for a White Male Effect in Generation Z: Race, Sex, and Political Effects on Environmental Concern and Ambivalence. Society \& Natural Resources, 31(8), 925-941. https://doi.org/10.1080/08941920.2018.1445331

Muralidharan, S., \& Sheehan, K. (2016). "Tax" and "Fee” Message Frames as Inhibitors of Plastic Bag Usage Among Shoppers: A Social Marketing Application of the Theory of Planned Behavior. Social Marketing Quarterly, 22(3), 200-217. https://doi.org/10.1177/1524500416631522

Nickerson, R. S. (2002). Psychology and Environmental Change. United Kingdom: Taylor \& Francis.

Pahl, S., \& Wyles, K. J. (2017). The human dimension: How social and behavioural research methods can help address microplastics in the environment. Analytical Methods, 9(9), 1404-1411. https://doi.org/10.1039/C6AY02647H

Palan, S., \& Schitter, C. (2017). Prolific.ac-A subject pool for online experiments. Journal of Behavioral and Experimental Finance, 17. https://doi.org/10.1016/j.jbef.2017.12.004

Royer, S.-J., Ferrón, S., Wilson, S. T., \& Karl, D. M. (2018). Production of methane and ethylene from plastic in the environment. PLOS ONE, 13(8), e0200574. https://doi.org/10.1371/journal.pone.0200574 
Sapiains, R., Beeton, R. J. S., \& Walker, I. A. (2016). Individual responses to climate change: Framing effects on pro-environmental behaviors. Journal of Applied Social Psychology, 46(8), 483-493. https://doi.org/10.1111/jasp.12378

Schlagloth, R., Santamaria, F., Golding, B., \& Thomson, H. (2018). Why is it Important to Use Flagship Species in Community Education? The Koala as a Case Study. Animal Studies Journal, 7(1), 127-148.

Septianto, F., \& Lee, M. S. W. (2019). Emotional responses to plastic waste: Matching image and message framing in encouraging consumers to reduce plastic consumption. Australasian Marketing Journal (AMJ). https://doi.org/10.1016/j.ausmj.2019.09.002

Simberloff, D. (1998). Flagships, umbrellas, and keystones: is single-species management passé in the landscape era?. Biological conservation, 83(3), 247-257.

Shen, M., Huang, W., Chen, M., Song, B., Zeng, G., \& Zhang, Y. (2020). (Micro)plastic crisis: Un-ignorable contribution to global greenhouse gas emissions and climate change. Journal of Cleaner Production, 254, 120138.

https://doi.org/10.1016/j.jclepro.2020.120138

Spence, A., \& Pidgeon, N. (2010). Framing and communicating climate change: The effects of distance and outcome frame manipulations. Global Environmental Change, 20(4), 656-667. https://doi.org/10.1016/j.gloenvcha.2010.07.002

Tversky, A., \& Kahneman, D. (1981). The Framing of Decisions and the Psychology of Choice. Science, 211, 453-457.

Vince, J., \& Stoett, P. (2018). From problem to crisis to interdisciplinary solutions: Plastic marine debris. Marine Policy, 96, 200-203. https://doi.org/10.1016/j.marpol.2018.05.006 
Von Mossner, A. W. (2018). Green states of mind? Cognition, emotion and environmental framing. Green Letters: Studies in Ecocritism, 22(3), 313-323. https://doi.org/10.1080/14688417.2018.1531723

Willis, K., Maureaud, C., Wilcox, C., \& Hardesty, B. D. (2018). How successful are waste abatement campaigns and government policies at reducing plastic waste into the marine environment? Marine Policy, 96, 243-249. https://doi.org/10.1016/j.marpol.2017.11.037

Wolsko, C., Ariceaga, H., \& Seiden, J. (2016). Red, white, and blue enough to be green: Effects of moral framing on climate change attitudes and conservation behaviors. Journal of Experimental Social Psychology, 65, 7-19. https://doi.org/10.1016/j.jesp.2016.02.005

Xiao, C., \& McCright, A. M. (2012). Explaining Sex Differences in Concern about Environmental Problems in the United States. Society \& Natural Resources, 25(11), 1067-1084. https://doi.org/10.1080/08941920.2011.651191

Zheng, J., \& Suh, S. (2019). Strategies to reduce the global carbon footprint of plastics. Nature Climate Change, 9(5), 374-378. https://doi.org/10.1038/s41558-019-0459-z 